\title{
Retrospective study of small pet tumors treated with Artemisia annua and iron
}

\author{
MOHAMED E.M. SAEED ${ }^{1 *}$, ELMAR BREUER ${ }^{2 *}$, MOHAMED-ELAMIR F. HEGAZY $^{1}$ and THOMAS EFFERTH ${ }^{1}$ \\ ${ }^{1}$ Department of Pharmaceutical Biology, Institute of Pharmacy and Biochemistry, Johannes Gutenberg University, Mainz, \\ D-55128 Rhineland-Palatinate; ${ }^{2}$ Veterinary Clinic for Small Animals, 'Alte Ziegelei' Müllheim, D-79379 Baden, Germany
}

Received February 26, 2019; Accepted October 7, 2019

DOI: 10.3892/ijo.2019.4921

\begin{abstract}
Artemisinin from Artemisia annua L. and its derivatives are well-known antimalarial drugs. In addition, in vitro studies, in vivo studies and clinical trials have demonstrated that these drugs exhibit anticancer activity in human patients with cancer. Therefore, the aim of the present study was to investigate whether a phytotherapeutic A. апnи a preparation exerts anticancer activity in veterinary tumors of small pets. Dogs and cats with spontaneous cancer $(n=20)$ were treated with standard therapy plus a commercial $A$. аппиа preparation (Luparte ${ }^{\circledR}$ ) and compared with a control group treated with standard therapy alone $(n=11)$. Immunohistochemical analyses were performed with formalin-fixed paraffin-embedded tumor biopsies to analyze the expression of transferrin receptor (TfR) and the proliferation marker Ki-67 as possible biomarkers to assess treatment response of tumors to A. аппиа. Finally, the expression levels of TfR and $\mathrm{Ki}-67$ were compared with the $\mathrm{IC}_{50}$ values towards artemisinin in two dog tumor cells lines (DH82 and DGBM) and a panel of 54 human tumor cell lines. Retrospectively, the present study assessed the survival times of small animals treated by standard therapy with or without A. аппиа. А. аппиа treatment was associated with a significantly higher number of animals surviving $>18$ months compared with animals without $A$. аnnua treatment $(\mathrm{P}=0.0331)$. Using a second set of small pet tumors, a significant correlation was identified between TfR and Ki-67 expression by immunohistochemistry $(\mathrm{P}=0.025)$. To further assess the association of transferrin and $\mathrm{Ki}-67$ expression with cellular response to artemisinin, the present study compared
\end{abstract}

Correspondence to: Professor Thomas Efferth, Department of Pharmaceutical Biology, Institute of Pharmacy and Biochemistry, Johannes Gutenberg University, Staudinger Weg 5, Mainz, D-55128 Rhineland-Palatinate, Germany

E-mail: efferth@uni-mainz.de

${ }^{*}$ Contributed equally

Abbreviations: NMR, nuclear magnetic resonance; TfR, transferrin receptor; TIL, tumor-infiltrating lymphocyte

Key words: artemisinin, Asteraceae, chemotherapy, natural products, phytotherapy, prognostic factors the expression of these two biomarkers and the $\mathrm{IC}_{50}$ values for artemisinin in National Cancer Institute tumor cell lines in vitro. Both markers were inversely associated with artemisinin response $(\mathrm{P}<0.05)$, and the expression levels of TfR and Ki-67 were significantly correlated $(\mathrm{P}=0.008)$. In conclusion, the promising results of the present retrospective study warrant further confirmation by prospective studies in the future.

\section{Introduction}

Laboratory animals are indispensable for biomedical research. They are used to develop disease models to better understand the pathogenesis of human diseases and to develop novel treatment options. In cancer research, transplanted syngeneic, xenografted and orthotopic tumor models or chemically induced tumors in mice or rats have been used for decades (1). Despite these widely used experimental animal models, it has been overlooked in human oncology that animals may suffer from spontaneously arising tumors in a comparable fashion to human patients. These spontaneous animal tumors are much closely associated with the situation in humans compared with experimental tumor models, as they arise spontaneously and are neither maintained by transplantation nor are they induced by chemical carcinogens (2). Therefore, spontaneous veterinary tumors represent an attractive, although underestimated, opportunity to study novel treatment strategies prior to clinical application in human patients with cancer. As the treatment of spontaneous tumors in animals is also of importance in veterinary medicine, studies on veterinary tumors are also of great impact for veterinary oncology. The survival prognosis of malignant tumors in small animals is far from satisfactory and the majority succumb to the disease even after application of surgical, radio- or chemotherapeutic interventions $(3,4)$. The clinical prognosis and clinical, pathological and biochemical factors influencing the survival of pets have been reported for dogs (5-9), cats (10-12), canines (13) and other species $(14,15)$. Despite considerable progress in treating both veterinary and human tumors, the situation remains poor and numerous patients succumb to their disease. Therefore, novel treatment options are urgently required.

The majority of clinically established drugs are derived from natural products (16). Therefore, the search for novel treatments appears to be most promising when using natural sources. A recent example for the validity of this concept is 
artemisinin. Artemisinin is a bioactive terpenoid isolated from Artemisia annua L., which is a medicinal herb that has been used for about two millennia in traditional Chinese medicine (17). The isolation of artemisinin from A. annua led to a novel treatment option of eminent importance for malaria. Artemisinin and its derivatives have been responsible for the survival of millions of patients with malaria $(18,19)$. This achievement was appreciated in 2015 with the conferment of the Nobel Prize for Medicine or Physiology to the Chinese scientist Youyou Tu (20). While artemisinin derivatives, such as artemether and artesunate, are well-established as anti-malarial drugs, herbal preparations of $A$. annua also inhibit Plasmodia infections in patients with malaria (21). Notably, the bioactivity of artemisinin is not restricted to malaria, and other diseases are also susceptible to artemisinin and A. annua treatment, such as schistosomiasis and trypanosomiasis (22-24), diverse viral infections (25) and diseases related to the metabolic syndromes, including obesity, diabetes and atherosclerosis (26-28).

Artemisinin derivatives also inhibit human tumor cell growth in vitro and in vivo (29-31). This is relevant not only for cancer therapy, but also for cancer prevention $(32,33)$. Artemisinin derivatives exert additive or synergistic interactions in combination with a wide array of clinically established drugs (34-36). This has also been demonstrated in veterinarian tumor cell lines in vitro and veterinarian clinical trials (37-39). Based on the anticancer activity in experimental tumor models, it has been possible to investigate the anticancer activity in human cancer patients in the form of compassionate uses $(40,41)$ and even to perform clinical phase I/II trials in human cancer patients (42-44). Another previous clinical phase I/II trial indicated the anticancer activity in a number of dogs with tumors (39). Preliminary results in three dogs and one cat revealed that a herbal preparation of $A$. annua (Luparte ${ }^{\circledR}$ ) may exhibit the potential to prolong the survival time of animals with tumors (45). To substantiate these preliminary results from the compassionate use of A. annua, the present study has performed a retrospective analysis by evaluating survival times of 25 pets treated with $A$. annua compared with 11 animals without $A$. annua treatment. Independent of $A$. annua food supplementation, all animals were subjected to standard treatment protocols. In addition, the expression of two biomarkers, transferrin receptor (TfR) and the proliferation marker Ki-67, was determined by immunohistochemistry analysis of tumor biopsies.

\section{Materials and methods}

Artemisinin determination in A. annua. Nuclear magnetic resonance (NMR) spectra were recorded on a Bruker 300 NMR spectrometer (Bruker Corporation). Reversed phase high-performance liquid chromatography (HPLC)-mass spectrometry (MS) analysis was performed on a Waters Alliance 2695 LC (Waters Corporation) coupled to a Quattro Ultima triple quadrupole MS (Waters Corporation) using the same separation conditions as described previously (46). The separation conditions were follow: Chromatogram column, $\mathrm{XBridge}^{\mathrm{TM}}$ column $(4.6 \times 150 \mathrm{~mm}, 5 \mu \mathrm{m})$; column temperature, $20^{\circ} \mathrm{C}$; and injection volume, $1 \mu \mathrm{l}$. Elution was performed at a flow rate of $1 \mathrm{ml} / \mathrm{min}$, using as the mobile phase a mixture of water (A) and acetonitrile (B). The samples were eluted using the following gradient: $0 \mathrm{~min}, 98.0 \% \mathrm{~A}$; 0-8 min, linear increase to $100 \% \mathrm{~B} ; 100 \%$ A held for $2 \mathrm{~min}, 11-12 \mathrm{~min}$, return to $98.0 \% \mathrm{~A}$. The final optimization of ESI source operation parameters were a nitrogen gas flow of $11 \mathrm{l} / \mathrm{min}$, nebulizer of 30 psi, capillary voltage of $\pm 2.4 \mathrm{kV}$ and a drying gas temperature of $250^{\circ} \mathrm{C}(\mathrm{N} 2)$. The Quattro Ultima triple quadrupole MS operated in multiple reaction monitoring mode with a resolution of $0.7 \mathrm{~m} / \mathrm{z}$. Electrospray ionization (positive mode) and photodiode array detection at $254 \mathrm{~nm}$ were performed.

Different batches of A. annua (Luparte ${ }^{\circledR}$ ) were determined by the Department of Pharmaceutical Biology, Johannes Gutenberg University (Mainz, Germany). This blinded approach was used as a quality measure to independently guarantee the presence of artemisinin in Luparte ${ }^{\circledR}$. Each batch of A. annua powder (2x10 g) was extracted with two different polarity solvents, methylene chloride and methanol, at room temperature for $24 \mathrm{~h}$. The extract was concentrated in vacuo to obtain a residue of 0.8 and $1.2 \mathrm{~g}$ for methylene chloride and methanol, respectively. Each extract was transferred to a small vial and kept dry at room temperature. Small crystals were formed, which were collected and washed with $n$-hexane and methylene chloride to remove extract residues. Then, ${ }^{1} \mathrm{H}$ and ${ }^{13} \mathrm{C}$ NMR analyses were performed.

Tumors. The animals were treated between 2010 and 2017. Briefly, 16 dogs (10 males and 6 females) and 4 cats ( 2 females, 1 male and 1 N/A) were treated with A. annua. The mean age of the dogs was 10.31 years and the mean age of the cats was 12.25 years. The mean weight of the dogs was $30.125 \mathrm{~kg}$ and the mean weight of the cats was $5.10 \mathrm{~kg}$. Tissue samples were taken from all animals and initially fixed at room temperature $\left(\sim 22^{\circ} \mathrm{C}\right)$ in $4 \%$ formaldehyde solution for $48 \mathrm{~h}$. Following fixation, the organs were trimmed, processed and embedded in paraffin wax at approximately $60^{\circ} \mathrm{C}$. Sections were cut to a thickness of $4 \mu \mathrm{m}$ and routinely stained with hematoxylin and eosin at room temperature. Histopathological examination of the hematoxylin and eosin-stained sections was performed under a light microscope in immersion oil with a Zeiss Axioskop. After routine pathological diagnosis, the paraffin blocks were used as excess material for subsequent immunohistochemical studies. Furthermore, the histological hematoxylin and eosin stained tumor sections were assessed for the presence of the tumor-infiltrating lymphocytes (TILs). The clinical data are presented in Tables I and II. The owners of the animals provided written informed consent for this retrospective study. The signed written consent forms are deposited at the Department of Pharmaceutical Biology, Johannes Gutenberg University (Mainz, Germany) and can be inspected upon reasonable demand.

Treatment protocol. The serum iron content was determined following collection of blood samples; a normal range is between 140 and $170 \mu \mathrm{g} / \mathrm{dl}$ (47). After initial iron content determination using ferrozine color test (48), the tumors were surgically removed with safety margins by a standard protocol after visual inspection and where required after lung radiography. Between blood collection and determination of the serum iron results from the clinical diagnosis laboratory, iron was administered orally [Ferrosanol ${ }^{\circledR}$ capsules 


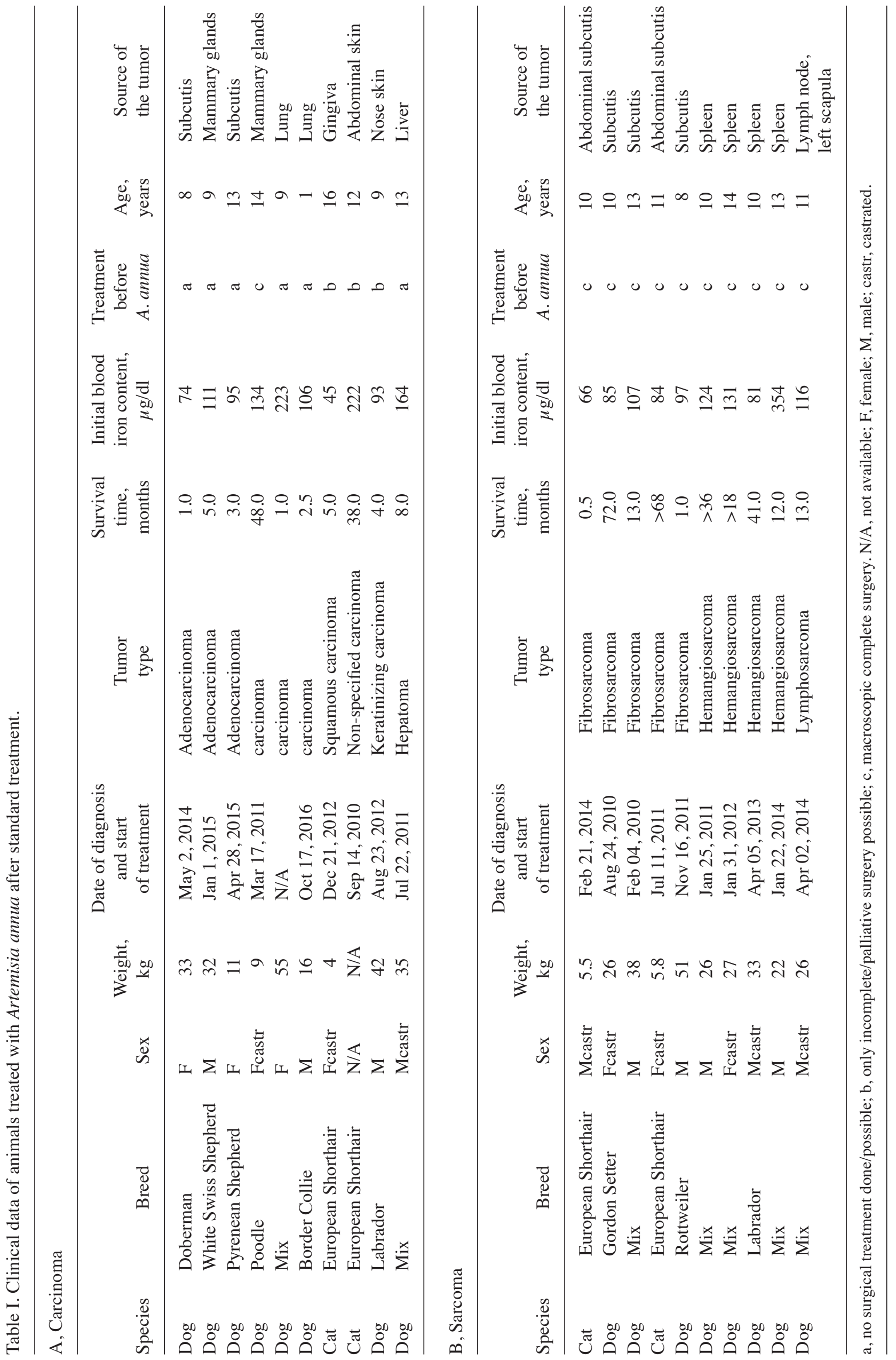




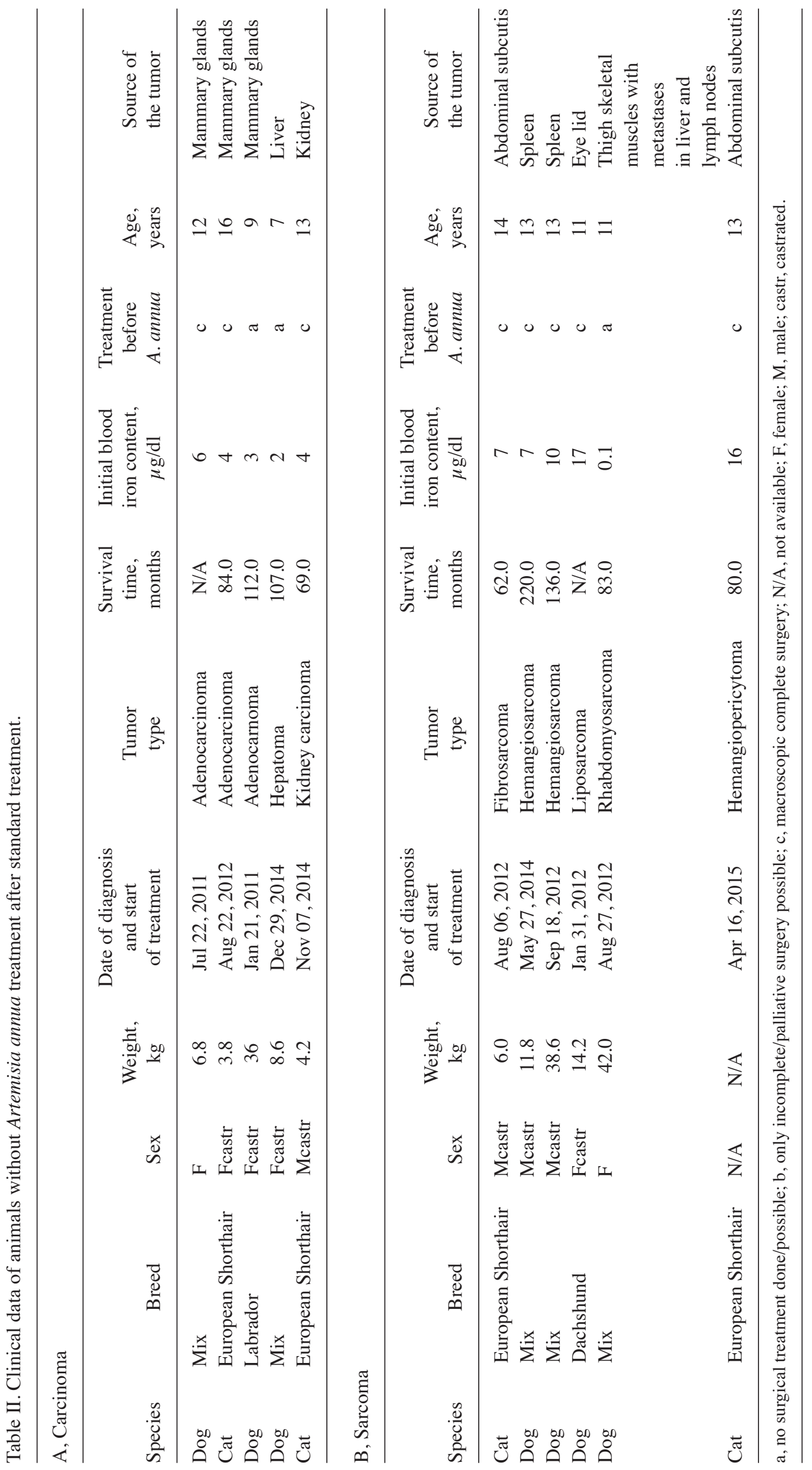


(100 $\mathrm{mg} /$ capsule or $40 \mathrm{mg} /$ capsule)]. The dosage was $100 \mathrm{mg} / 30 \mathrm{~kg}$ BW twice daily mixed into vegetable-poor food to avoid iron binding plant molecules, such as phytane, oxalates and/or phosphates. Alternatively, iron was subcutaneously injected (Myofer ${ }^{\circledR} /$ Ursoferran $^{\circledR} ; 100 \mathrm{mg} / \mathrm{ml}$ ) at a dose of $100 \mathrm{mg} / 10 \mathrm{~kg} \mathrm{BW}$ daily, until the serum iron results were obtained back from the clinical laboratory. The iron substitution was individually continued until an iron content of $250 \pm 30 \mu \mathrm{g} / \mathrm{dl}(\sim 43 \pm 5 \mu \mathrm{mol} / \mathrm{l})$ was stably reached in blood serum. From the fourth day of the initial iron substitution onward, the animals were orally treated with Luparte ${ }^{\circledR}$ capsules at a dosage of $1,400 \mathrm{mg} / \mathrm{m}^{2}$ body surface divided to three fractions per day (Table III). The capsules were administered 1-2 h before the next meal. The serum iron content was regularly monitored and where necessary adapted to $250 \pm 30 \mu \mathrm{g} / \mathrm{dl}$.

The treatment details and the follow-up information, including survival times, have been recorded in the clinical documentation files. All ethical issues have been discussed prior to evaluation of clinical and experimental data with the Regierungspräsidium (Government Presidium) Freiburg (Germany). According to the design of this retrospective study, the Regierungspräsidium (Government Presidium) Freiburg gave written permission for the present study (Az. 35-9185.81/1, dated from February 4th, 2019).

Cell lines. The D-GBM cell line was generated by Dr George Stoica (Department of Veterinary Pathobiology, Texas A\&M University, College Station, TX, USA) from a brain tumor of an 8-year-old male Boxer dog (49). The D-GBM cells used in the present study were obtained from Dr Pablo Steinberg (Institute for Food Toxicology and Analytical Chemistry, University of Veterinary Medicine Hannover, Hannover, Germany), who obtained it from Dr G. Stoica.

The histiocytic DH82 cell line was generated by Dr M.L. Wellman (Department of Veterinary Pathobiology, College of Veterinary Medicine, Ohio State University, CO, USA) (50). The DH82 cell line used in the present study was also obtained from Dr Pablo Steinberg, who purchased it from the European Tissue Culture Collection (catalog no. 94062922).

A panel of 54 human tumor cell lines of the Developmental Therapeutics Program (DTP) of the National Cancer Institute consisted of cell lines derived from leukemia, melanoma, non-small cell lung cancer, colon cancer, renal cancer, ovarian cancer, breast cancer and prostate carcinoma, as well as central nervous system tumors (51). Previously, the cytotoxicity of cells treated with artemisinin for $48 \mathrm{~h}$ was evaluated using a sulforhodamine $\mathrm{B}$ assay (52). The $\log _{10} \mathrm{IC}_{50}$ values for artemisinin and mRNA expressions for Ki-67 and TfR were available publicly in the DTP database (https://dtp.cancer.gov/default.htm).

Cytotoxicity assay. A resazurin reduction assay (Promega Corporation) was performed as previously described (53) to assess the cytotoxicity of artemisinin, artesunate and dihydroartemisinin towards the dog tumor cell lines DH82 and DGBM. The concept of the assay is based on the metabolic reduction of the non-fluorescent dye by living cells to the strongly-fluorescent dye resorufin (54). $\mathrm{IC}_{50}$ values were calculated from dose-response curves using a non-linear regression analysis tool in GraphPad Prism 7 software (GraphPad Prism, Inc.). All $\mathrm{IC}_{50}$ values are expressed as the mean \pm standard deviation.
Each assay was performed thrice independently, with six replicates each.

Immunohistochemistry. A total of 17 tumor tissues representing different tumor types in pets were collected to evaluate the expression of Ki-67 and TfR in animal tumors (Table V). Briefly, tumor tissues were obtained from 15 dogs ( 7 males and 8 females) and 2 cats (both female). The mean age of the dogs was 9.33 years and the mean age of the cats was 4 years. The mean weight of the dogs was $27.266 \mathrm{~kg}$ and the mean weight of the cats was $4.00 \mathrm{~kg}$. All the chosen animals had been kept in pet animal housing conditions. The immunohistochemical staining of tumor tissues was performed as described previously (55). The slides were washed twice with xylene (98.5\% xylene for $5 \mathrm{~min}$ each at room temperature) to remove paraffin. Then, sample tissues were rehydrated through graded washes with isopropanol in water. Heat-induced epitope retrieval was performed using a pressure cooker as a heating device. Ultra-vision protein block and UltraVision Hydrogen Peroxide Block (catalog nos. TA-060-UB and TA-060-H2O2Q, respectively; Thermo Fisher Scientific, Inc.) were added to block endogenous proteins and endogenous peroxidase activity, respectively, to avoid non-specific background staining. Overnight incubation at $4^{\circ} \mathrm{C}$ was performed following the addition of monoclonal primary antibodies. For the detection of Ki-67, the SP6 clone (catalog no. ab16667; Abcam) was used at a dilution of 1:200. For the determination of TfR expression, the H68.4 clone (catalog. no. 136800; Thermo Fisher Scientific, Inc.) was applied at a dilution of 1:100. Subsequently, horseradish peroxidase-labeled polymers conjugated with secondary antibodies specific for both mouse and rabbit primary antibodies were added (catalog nos. TL-060-QPH and TL-060-QPB; Thermo Fisher Scientific, Inc.) at room temperature for $1 \mathrm{~h}$, according to the manufacturer's protocol. The final staining reaction was performed with diaminobenzidine and slides were counterstained with hematoxylin for $3 \mathrm{~min}$ at room temperature.

The immunostaining of DH82 and DGBM cell lines was performed without the rehydration or epitope retrieval steps. Briefly, six cover slips were placed in a 6-well plate, then $5 \times 10^{5}$ cells/well were seeded over the cover slips and incubated in humidified $5 \% \mathrm{CO}_{2}$ atmosphere at $37^{\circ} \mathrm{C}$ overnight to let the cells attach to coverslips. Subsequently, the cells were fixed in $4 \%$ paraformaldehyde for $15 \mathrm{~min}$ at room temperature, and the blocking and staining steps were performed as described for the tissue section. However, the Ki-67 and TfR antibodies were diluted at 1:500 and 1:1,000, respectively. The immunostained slides were scanned using Pannoramic Desk (3DHISTECH Ltd.) and the amount of Ki-67- or TfR-expressing cells was quantified by Pannoramic Viewer software version 1.15 (3DHISTECH Ltd.).

Statistical analysis. Significance values and correlation coefficients were calculated using Pearson's correlation coefficient and Fisher's exact test with the WinSTAT software program version 2012.1 (www.winstat.com/). Linear regression was performed using Excel 2016 (Microsoft Corporation) for the $\log _{10} \mathrm{IC}_{50}$ values for artemisinin and mRNA expressions for Ki-67 and TfR. $\mathrm{P}<0.05$ was considered to indicate a statistically significant difference. 
Table III. Conversion table for Luparte ${ }^{\circledR}$ treatment.

\begin{tabular}{cc}
\hline Body weight, $\mathrm{kg}$ & Body surface, $\mathrm{m}^{2}$ \\
\hline 0.5 & 0.06 \\
1 & 0.1 \\
2 & 0.16 \\
5 & 0.29 \\
10 & 0.46 \\
15 & 0.61 \\
20 & 0.74 \\
30 & 0.97 \\
40 & 1.17 \\
50 & 1.36 \\
60 & 1.63 \\
70 & 1.7 \\
\hline
\end{tabular}

\section{Results}

Identification of artemisinin. As presented in Fig. 1A, the ${ }^{1} \mathrm{H}$ NMR spectrum of a colorless crystal contained signals typical of artemisinin. The spectrum displayed signals for three methyl groups: Two secondary at $\delta_{\mathrm{H}} 1.00(\mathrm{~d}, J=6.5$, $\mathrm{H}-14), 1.17$ (d, $J=7.2, \mathrm{H}-13)$ and one tertiary methyl signal at $\delta_{\mathrm{H}} 1.40(\mathrm{~s}, \mathrm{H}-15)$. Additionally, two aliphatic methylene signals were observed at $\delta_{\mathrm{H}} 2.12$ (brddd, $J=14.9,4.2,2.6$ ) and 2.40 (ddd, $J=14.9,13.1,4.1$ ) for $\mathrm{H}-3 \mathrm{a}$ and $\mathrm{H}-3 \mathrm{~b}$, respectively. A characteristic downfield singlet signal at $\delta_{H} 6.01$ indicated the presence of oxygenated proton for $\mathrm{H}-5$. As presented in Fig. 1B, The ${ }^{13} \mathrm{C}$ NMR spectrum displayed 15 major carbon signals, including significant carbons signals confirming the presence for artemisinin as the following: $\delta_{\mathrm{C}} 173.3$ (s, C-12), 105.2 (s, C-4), 94.3 (d, C-5) and 79.5 (s, C-6) (56).

Reversed phase HPLC-MS was used to quantitatively analyze the presence of artemisinin. Fig. $1 \mathrm{C}$ presents the chromatogram obtained after dissolving $2 \mathrm{mg} / \mathrm{ml} \mathrm{MeOH}$ extract, which indicated that artemisinin represents $3.46 \%$ of the A. annua (Luparte ${ }^{\circledR}$ ) extract.

Clinical treatment. In total, 23 dogs and 8 cats were included in the present study. Among these, 20 were treated with A. annua in addition to their standard therapy (Table I) and 11 were subjected to standard treatment alone (Table II). The A. annua-treated group consisted of 10 carcinomas ( $8 \mathrm{dogs}$, 2 cats) and 10 sarcomas ( 8 dogs, 2 cats). All animals were treated between 2010 and 2017 (Table I). In the group of animals without $A$. annua treatment, 5 animals presented with carcinoma ( 3 dogs, 2 cats) and 6 animals had sarcoma (4 dogs, 2 cats) (Table II). The blood iron content and the survival times of all pets were recorded.

The effect of $A$. annua treatment on overall survival time was assessed. In total, 13 A. annua-treated animals and 11 non-treated animals exhibited a survival time of $<18$ months following therapy. Whereas, 7 animals in the $A$. annua-treated group had a survival time of $>18$ months after $A$. annua treatment, but no animals in the non-treated group survived $>18$ months. This difference in survival times between the
Table IV. Correlation of Luparte ${ }^{\circledR}$ treatment and survival time.

\begin{tabular}{lcc}
\hline Survival time, (months) & Treatment & No treatment \\
\hline$<18$ & 13 & 11 \\
$\geq 18$ & 7 & 0 \\
\hline
\end{tabular}

$\mathrm{P}=0.033$ according to Fisher's exact test.

groups was statistically significant $(\mathrm{P}=0.033$; two-tailed Fisher's exact test; Table IV).

Histology and immunohistochemistry. Using a second collection of 17 tumors, the histology of the tumors was determined by hematoxylin and eosin staining of formalin-fixed and paraffin-embedded tumor sections. Representative photographs of different tumor histology are presented in Fig. 2, including a tubulopapillary breast adenocarcinoma, soft tissue sarcoma, squamous cell carcinoma and neuroendocrine carcinoma.

Furthermore, immunohistochemical analyses were performed. The membrane-bound expression of TfR (CD71) and the nuclear expression of the proliferation marker Ki-67 were determined. The percentage of stained cells was quantified using a computer-based quantification system. Six different areas were selected from each tumor section to provide representative expression values. The percentage of TfR-expressing cells ranged between $43.5( \pm 37.9 \%)$ and $99.2 \%( \pm 0.2 \%)$, whereas the percentage of $\mathrm{Ki}-67$-positive cells was in a range between $6.6( \pm 1.8 \%)$ and $85.7 \%( \pm 4.7 \%)$ (Fig. 3A and B). As tumor heterogeneity plays an important role in the response to anticancer therapy, the present study also focused on heterogeneous and homogeneous staining patterns among the different tumor biopsies. Certain tumors were very heterogeneous in the immunohistochemical staining, while others revealed uniform staining. This can be seen in the standard deviations, which ranged between 0.1 (cases no. 3, 8 and 13) and $37.9 \%$ (case 10) for TfR, and between 1.8 (case 17) and 16.3\% (case 8) for Ki-67 (Table V). Subsequently, the correlation between the expression of TfR and Ki-67 with the set of tumor biopsies was investigated, which revealed a statistically significant correlation $(\mathrm{P}=0.025$; $\mathrm{r}=0.469$; Fig. $3 \mathrm{C})$. No significant correlation was identified between blood iron content and survival time of the animals ( $\mathrm{P}=0.386 ; \mathrm{r}=-0.062$; Fig. 3D). Notable, the association between survival time and A. annua treatment was significant. Pets treated with standard therapy plus A. annua has significantly longer survival times compared with those treated with standard therapy alone ( $\mathrm{P}=0.033$; Fig. 3E).

As the direct association between TfR and Ki-67 expression and the cytotoxicity of artemisinin could not be assessed in these tumor samples, the TfR and Ki-67 microarray-based mRNA expression in 54 human tumor cell lines was analyzed compared with the $\log _{10} \mathrm{IC}_{50}$ values, as determined by sulforhodamine assay. Both TfR and Ki-67 expression were significantly negatively correlated with the cytotoxicity of artemisinin in these cell lines $(\mathrm{P}<0.05 ; \mathrm{r}<-0.20)$, which indicates a higher expression of these two markers was associated with a higher sensitivity of the cell lines to artemisinin (Table VI). The expression levels of TfR and Ki-67 were positively correlated $(\mathrm{P}=0.008 ; \mathrm{r}=0.317)$. This panel of 
A

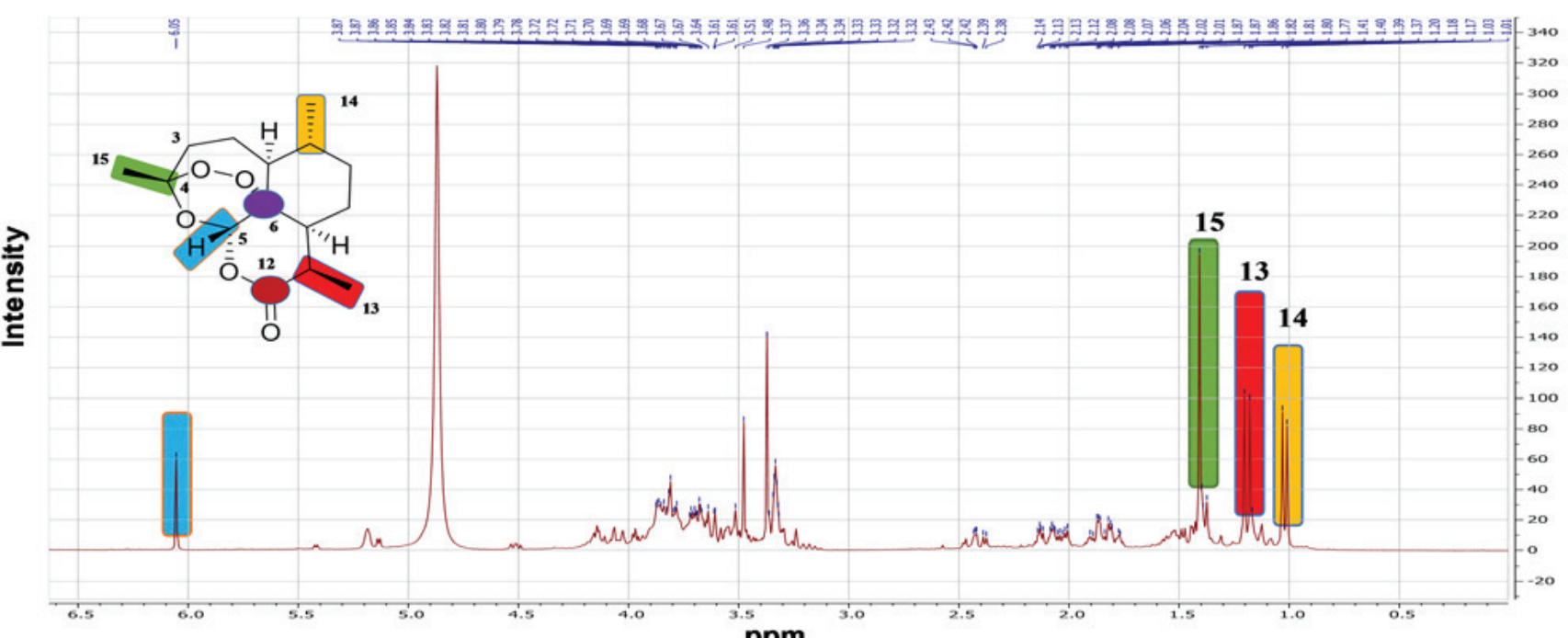

B

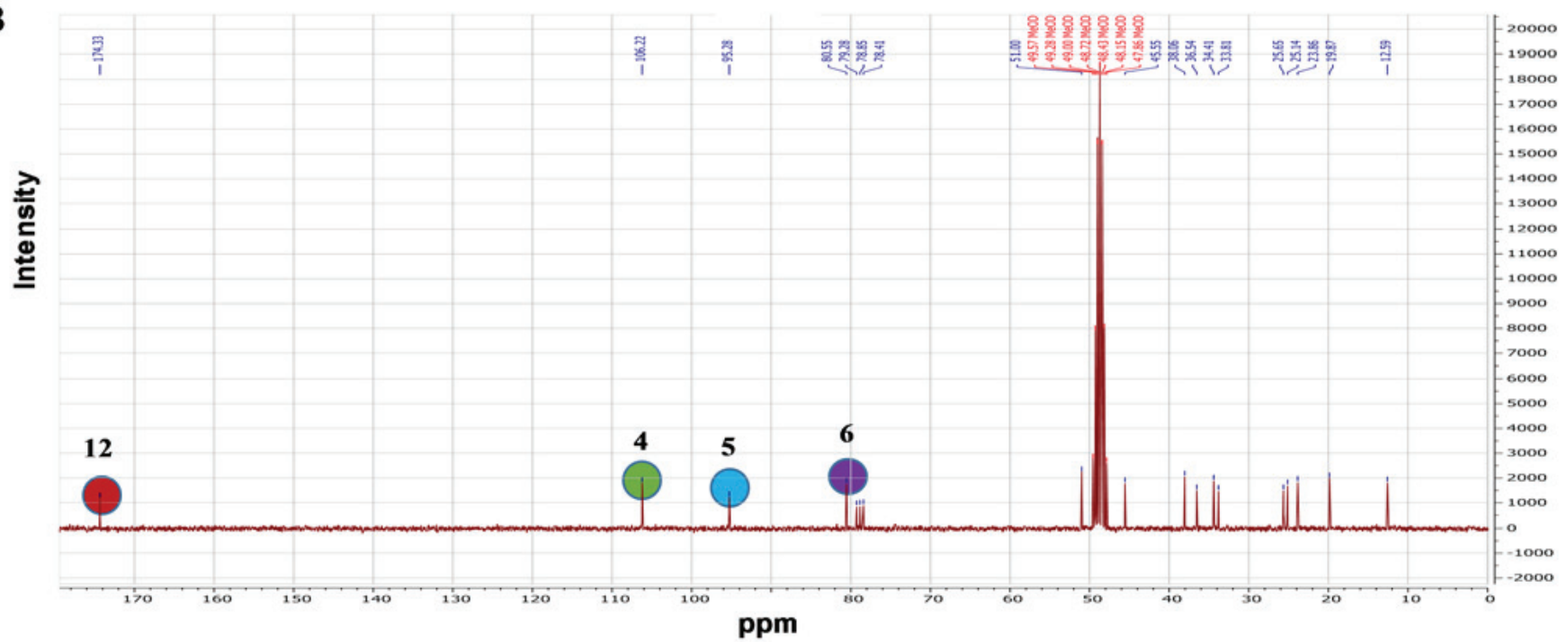

C

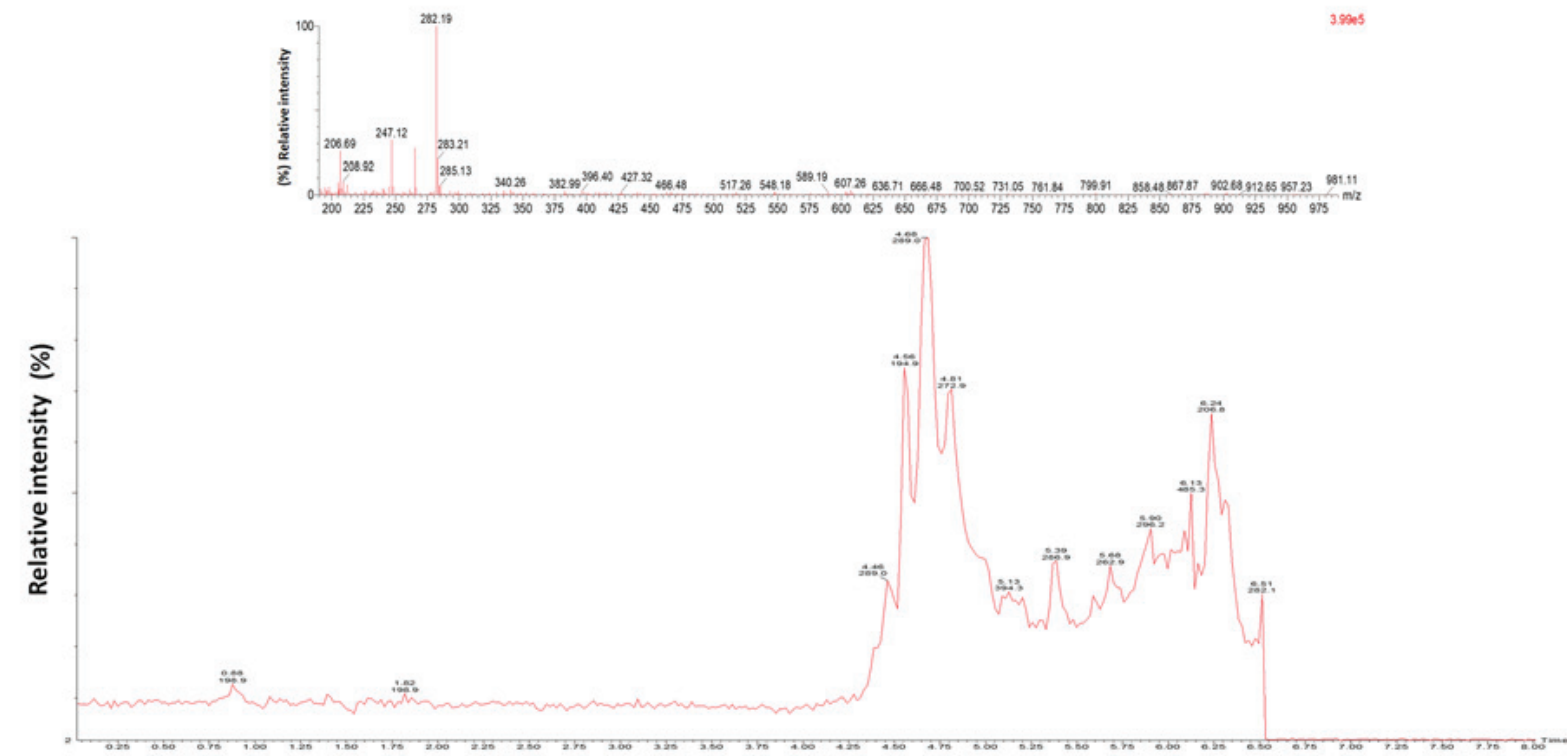

Figure 1. NMR spectra of A. апnиa chloroform extract demonstrating the presence of artemisinin. (A) ${ }^{1} \mathrm{H} \mathrm{NMR}(300 \mathrm{MHz})$. (B) ${ }^{13} \mathrm{C} \mathrm{NMR}(75 \mathrm{MHz})$. (C) RP-HPLC/MS chromatogram of A. аппиа $\left(\right.$ Luparte $\left.^{\circledR}\right)$ extract. The top figure shows the MS profile, while the bottom figure represents the HPLC measurements. NMR, nuclear magnetic resonance; RP-HPLC/MS, reversed phase high-performance liquid chromatography-mass spectrometry. 
A Tubulopapillary breast adeno $\mathrm{Ca}(\# 1)$

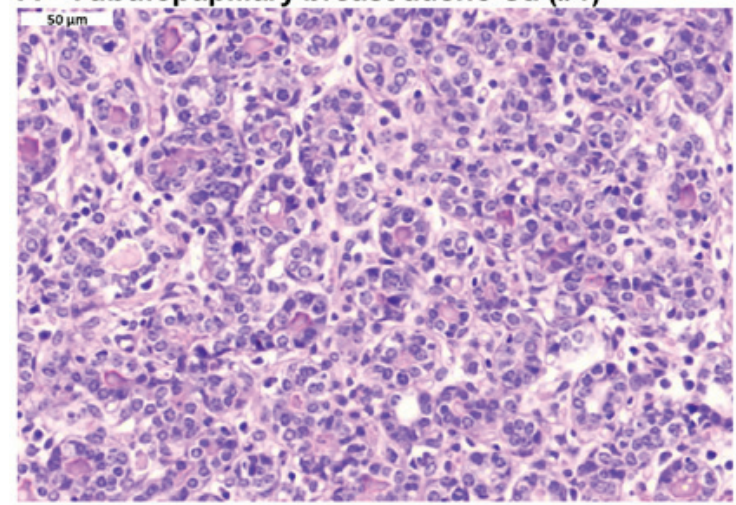

C Squamous cell carcinoma (\#16)

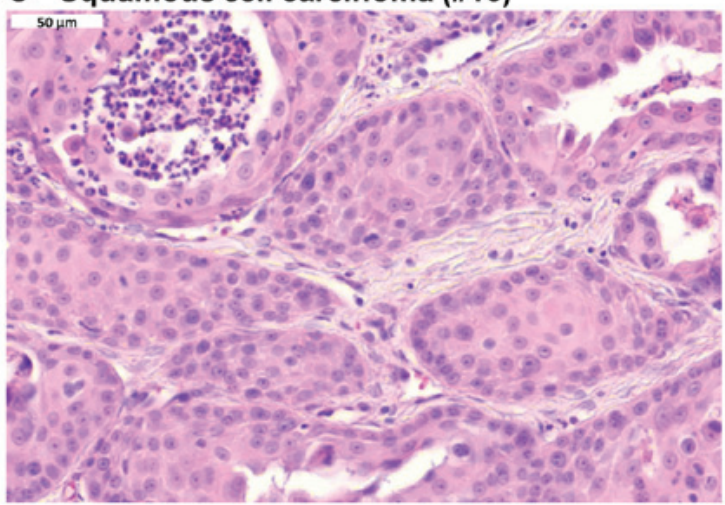

B Soft tissue sarcoma (\#3)

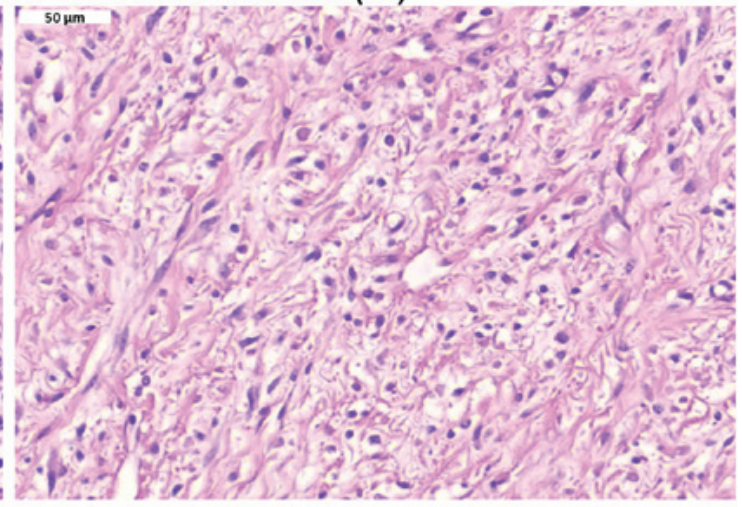

D Neuroendocrine carcinoma (\#11)

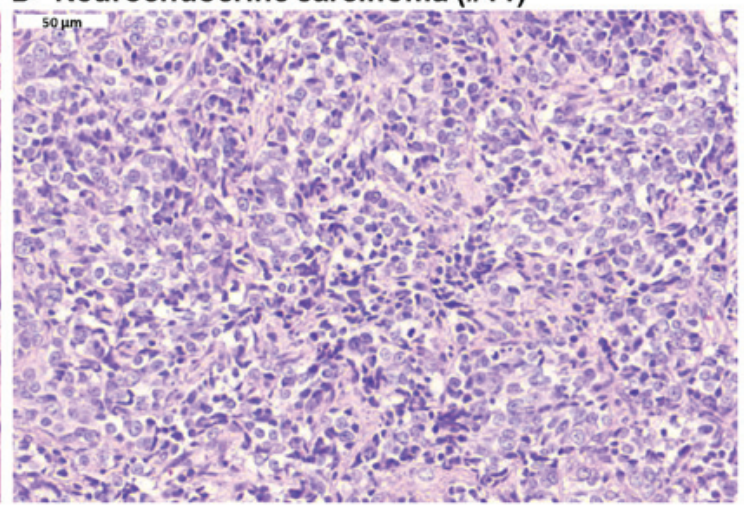

Figure 2. Hematoxylin and eosin staining of diverse pet tumors. (A) Tubulopapillary breast adenocarcinoma. (B) Soft tissue sarcoma. (C) Squamous cell carcinoma. (D) Neuroendocrine carcinoma. Magnification, x40.

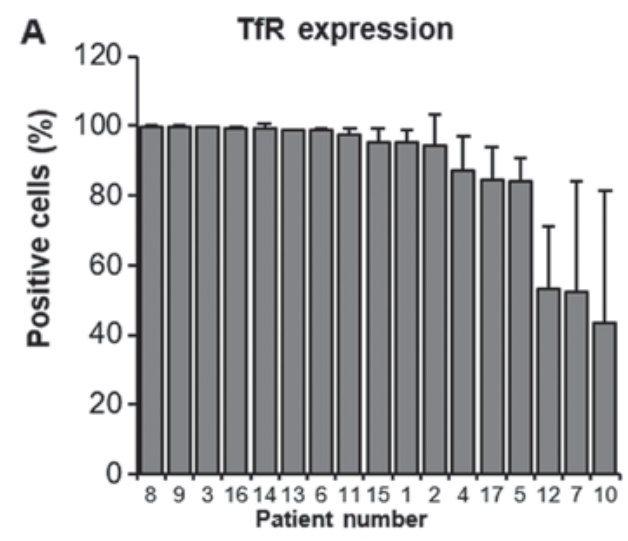

C

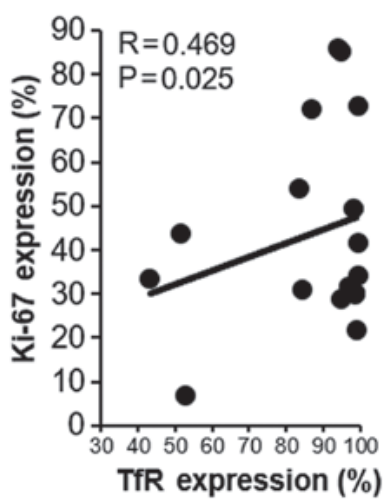

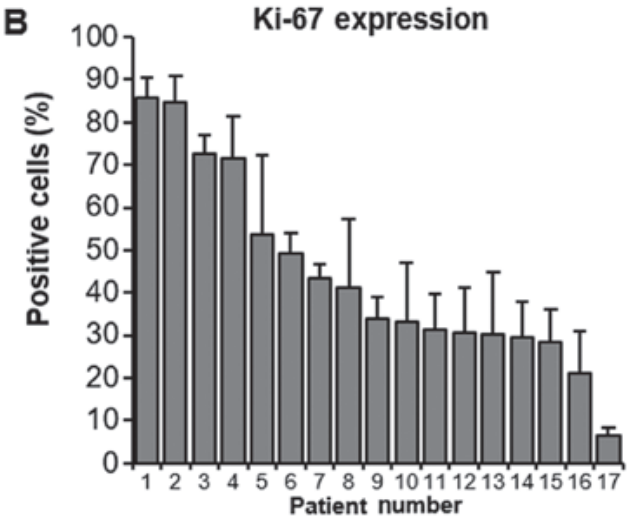

E

Survival time

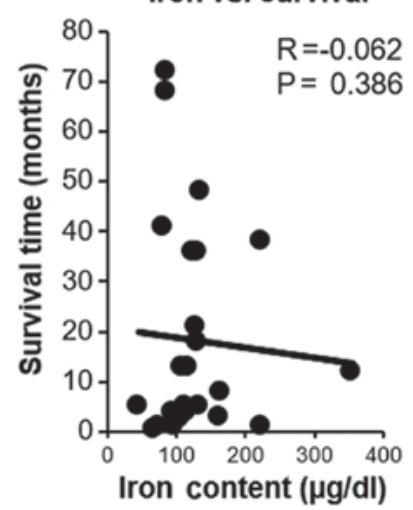

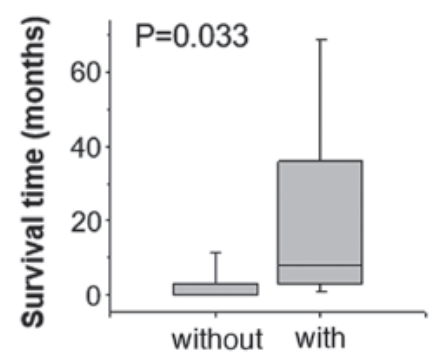

A. annua treatment

Figure 3. Quantification of immunohistochemical staining of veterinary tumors and correlation to clinical parameters. (A) TfR expression. (B) Ki-67 expression. (C) Correlation of TfR expression to Ki-67 expression. (D) Correlation of blood iron content to survival time. (E) Survival time of treated and untreated animals $(\mathrm{P}=0.033)$. Regression analyses were performed using Excel (Microsoft Corporation). TfR, transferrin receptor. 
Table V. Expression of TfR and the proliferation marker Ki-67 in dog tumors according to immunohistochemistry.

\begin{tabular}{|c|c|c|c|c|c|c|c|c|}
\hline Case & Species & Breed & Sex & $\begin{array}{l}\text { Weight, } \\
\text { kg }\end{array}$ & $\begin{array}{l}\text { Age, } \\
\text { years }\end{array}$ & $\begin{array}{l}\text { Percentage of } \\
\text { TfR-positive } \\
\text { cells }\end{array}$ & $\begin{array}{l}\text { Percentage- } \\
\text { of Ki-76 } \\
\text { postive cells }\end{array}$ & Histology \\
\hline 1 & Cat & European shorthair & Fcastr & 4 & 3 & $94.3 \pm 9.0$ & $85.7 \pm 4.7$ & $\begin{array}{l}\text { Tubulopapillary breast } \\
\text { adenocarcinoma }\end{array}$ \\
\hline 2 & Dog & Mix & Fcastr & 17 & 13 & $95.1 \pm 3.6$ & $84.8 \pm 5.9$ & $\begin{array}{l}\text { Tubulopapillary breast } \\
\text { adenocarcinoma }\end{array}$ \\
\hline 3 & Dog & Weimarian & M & 28 & 8 & $99.7 \pm 0.1$ & $72.5 \pm 4.4$ & $\begin{array}{l}\text { Soft tissue sarcoma, } \\
\text { Grade } 1\end{array}$ \\
\hline 4 & Dog & Deutsch-Adrahthaar & Fcastr & 28 & 9 & $87.2 \pm 9.6$ & $71.6 \pm 9.7$ & $\begin{array}{l}\text { Tubulopapillary breast } \\
\text { adenocarcinoma with } \\
\text { lymph node metastasis }\end{array}$ \\
\hline 5 & Dog & French bulldog & Mcastr & 11 & 7 & $83.9 \pm 6.8$ & $53.5 \pm 18.7$ & $\begin{array}{l}\text { Soft tissue sarcoma, } \\
\text { Grade } 1\end{array}$ \\
\hline 6 & Dog & $\begin{array}{l}\text { American Staffordshire } \\
\text { Terrier }\end{array}$ & Mcastr & 33 & 3 & $98.6 \pm 0.5$ & $49.1 \pm 4.9$ & Mastocytoma, Type 2 \\
\hline 7 & Dog & Mix & M & 21 & 12 & $52.1 \pm 32.1$ & $43.5 \pm 3.1$ & Hemangiosarcoma \\
\hline 8 & Dog & Podenco & Fcastr & 24 & 12 & $99.9 \pm 0.1$ & $41.1 \pm 16.3$ & Osteosarcoma \\
\hline 9 & Dog & Blue lacy & M & 26 & 11 & $99.8 \pm 0.2$ & $33.9 \pm 5.0$ & Mastocytoma, Type 2 \\
\hline 10 & Dog & Mix & $\mathrm{F}$ & 14 & 2 & $43.5 \pm 37.9$ & $33.2 \pm 13.8$ & Mastocytoma, Type 2 \\
\hline 11 & Cat & European shorthair & Fcastr & 4 & 5 & $97.4 \pm 1.8$ & $31.3 \pm 8.3$ & $\begin{array}{l}\text { Neuroendocrine } \\
\text { carcinoma }\end{array}$ \\
\hline 12 & Dog & Podenco & Fcastr & 25 & 12 & $84.6 \pm 9.5$ & $30.5 \pm 10.7$ & $\begin{array}{l}\text { Osteosarcoma, highly } \\
\text { malignant }\end{array}$ \\
\hline 13 & Dog & Rottweiler & Fcastr & 51 & 8 & $99.0 \pm 0.1$ & $30.1 \pm 14.6$ & $\begin{array}{l}\text { Adenocarcinoma } \\
\text { metastasis }\end{array}$ \\
\hline 14 & Dog & Mix & Mcastr & 27 & 10 & $99.1 \pm 1.4$ & $29.5 \pm 8.4$ & $\begin{array}{l}\text { Teleangiectatic } \\
\text { osteosarcoma }\end{array}$ \\
\hline 15 & Dog & Labrador mix & $\mathrm{F}$ & 37 & 12 & $95.2 \pm 3.9$ & $28.6 \pm 7.4$ & Carcinoma \\
\hline 16 & Dog & Labrador & M & 43 & 9 & $99.2 \pm 0.6$ & $21.3 \pm 9.7$ & $\begin{array}{l}\text { Squamous cell } \\
\text { carcinoma }\end{array}$ \\
\hline 17 & Dog & Podenco & Fcastr & 24 & 12 & $53.3 \pm 17.8$ & $6.6 \pm 1.8$ & $\begin{array}{l}\text { Breast carcinoma, } \\
\text { complex/myxoid }\end{array}$ \\
\hline
\end{tabular}

Data are present as the mean \pm standard deviation. F, female; M, male; castr, castrate; TfR, transferrin receptor.

Table VI. Correlation of artemisinin ( $\log _{10} \mathrm{IC}_{50}$ values) with microarray-based TfR and Ki-67 mRNA expression in 54 human tumor cell lines.

\begin{tabular}{lcc}
\hline Marker & $\begin{array}{c}\text { Artemisinin } \\
\text { cytotoxicity }\end{array}$ & $\begin{array}{c}\text { Ki-67 } \\
\text { expression }\end{array}$ \\
\hline TfR expression & & \\
r value & -0.282 & 0.317 \\
P-value & 0.019 & 0.008 \\
Ki-67 expression & & \\
r value & -0.239 & \\
P-value & 0.041 & \\
\hline
\end{tabular}

TfR, transferrin receptor.
54 human tumor lines consisted of cell lines derived from eight tumor types (leukemia, melanoma and brain tumor, and carcinoma of colon, breast, ovary, kidney and prostate). The number of cell lines of each tumor type $(n=1-9)$ was too low to reveal significant correlations except for the three following results. In lung cancer cell lines, the $\log _{10} \mathrm{IC}_{50}$ values of artemisinin were inversely correlated with the $\mathrm{Ki}-67$ expression $(\mathrm{P}=0.009 ; \mathrm{r}=-0.759)$. In melanoma cell lines, the expression levels of Ki-67 and TfR were significantly correlated $(\mathrm{P}=0.010$; $\mathrm{r}=0.787)$. In renal cancer cell lines, the expression levels of Ki-67 and TfR were also significantly correlated ( $\mathrm{P}=0.019$; $r=0.781$ ) (data not shown). Since all other associations between artemisinin response and the expression of Ki-67 and TfR were not statistically significant, reliable conclusions on the role of Ki-67 and TfR may be drawn from the cell line panel as a whole, but not from tumor type-specific subsets. 
Transferrin receptor

A Tubulopapillary breast adeno $\mathrm{Ca}(\# 1)$
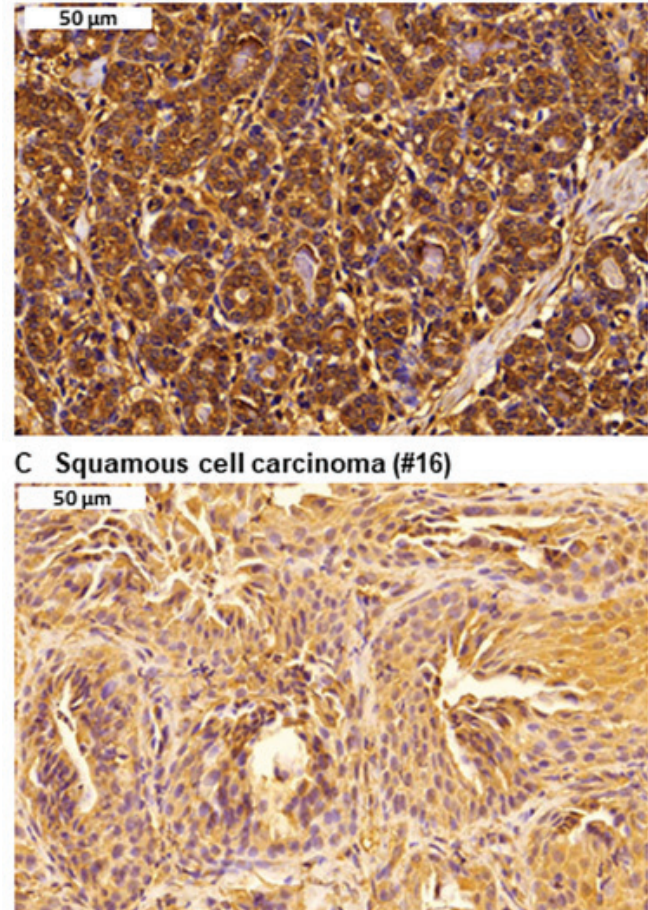

Ki-67

E Tubulopapillary breast adeno $\mathrm{Ca}$ (\#1)

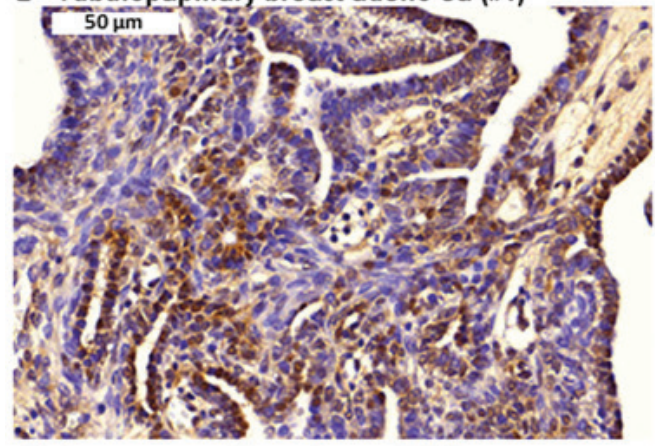

G Squamous cell carcinoma (\#16)

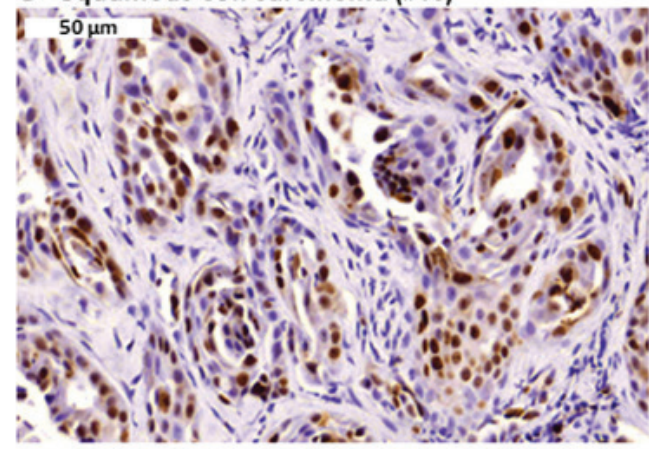

B Soft tissue sarcoma (\#3)

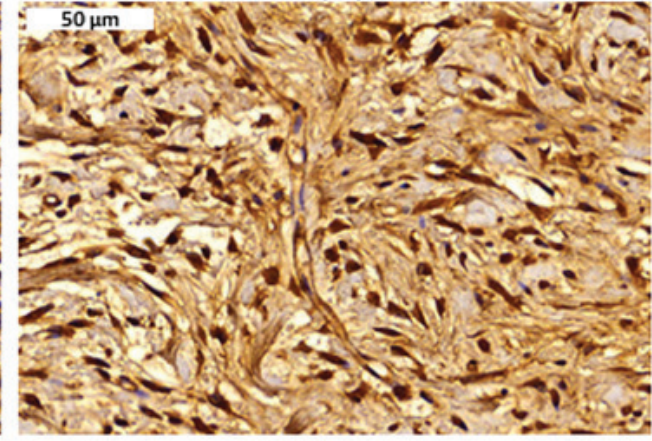

D Negative control (\#8)

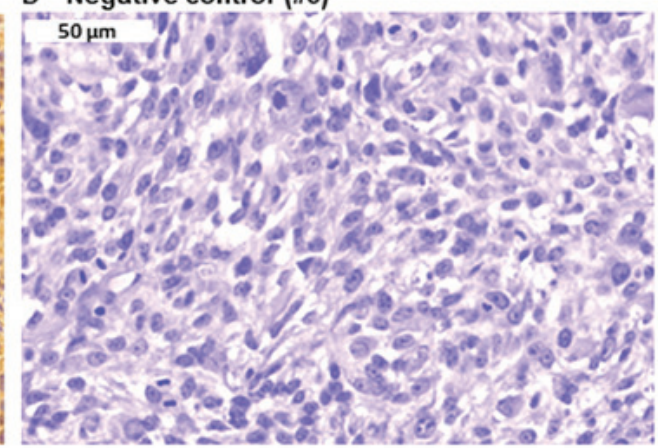

F Soft tissue sarcoma (\#5)

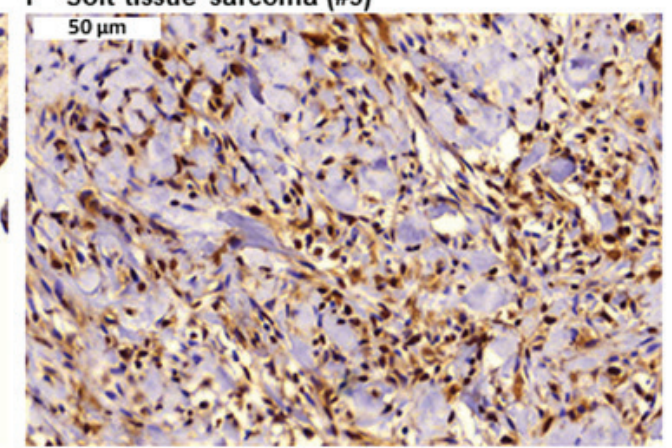

H Neuroendocrine carcinoma (\#11)

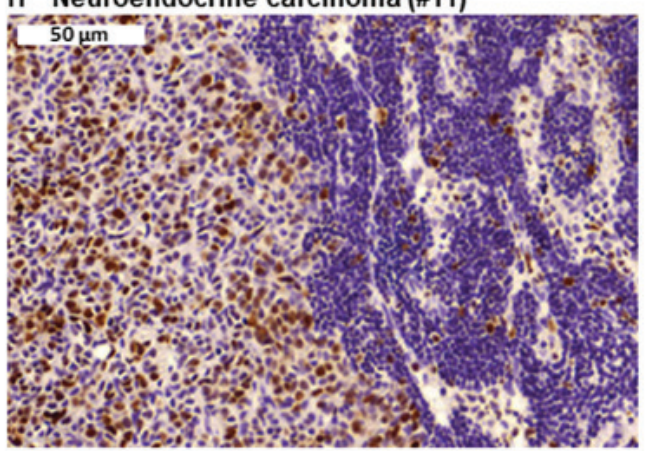

Figure 4. Detection of TfR and Ki-67 expression by immunohistochemistry. (A) TfR in tubulopapillary breast adenocarcinoma. (B) TfR in soft tissue sarcoma. (C) TfR in squamous cell carcinoma. (D) TfR in the negative control. (E) Ki-67 in tubulopapillary breast adenocarcinoma. (F) Ki-67 in soft tissue sarcoma. (G) Ki-67 in squamous cell carcinoma. (H) Ki-67 in neuroendocrine carcinoma. Magnification, x40. TfR, transferrin receptor.

Representative images of immunostaining for TfR expression are presented in Fig. 4A-D. Strong TfR expression was identified in biopsies of tubulopapillary breast adenocarcinoma, soft tissue sarcoma and squamous cell carcinoma. By contrast, the negative control did not demonstrate any reactivity, indicating the specificity of the immunostaining procedure. Furthermore, examples of Ki-67 expression in tubulopapillary breast adenocarcinoma, soft tissue sarcoma, squamous cell carcinoma and neuroendocrine carcinoma are presented in Fig. 4E-H. Furthermore, assessment of the presence of TILs in hematoxylin and eosin stained tumor tissues revealed an absence of TILs in all tumor slides. 


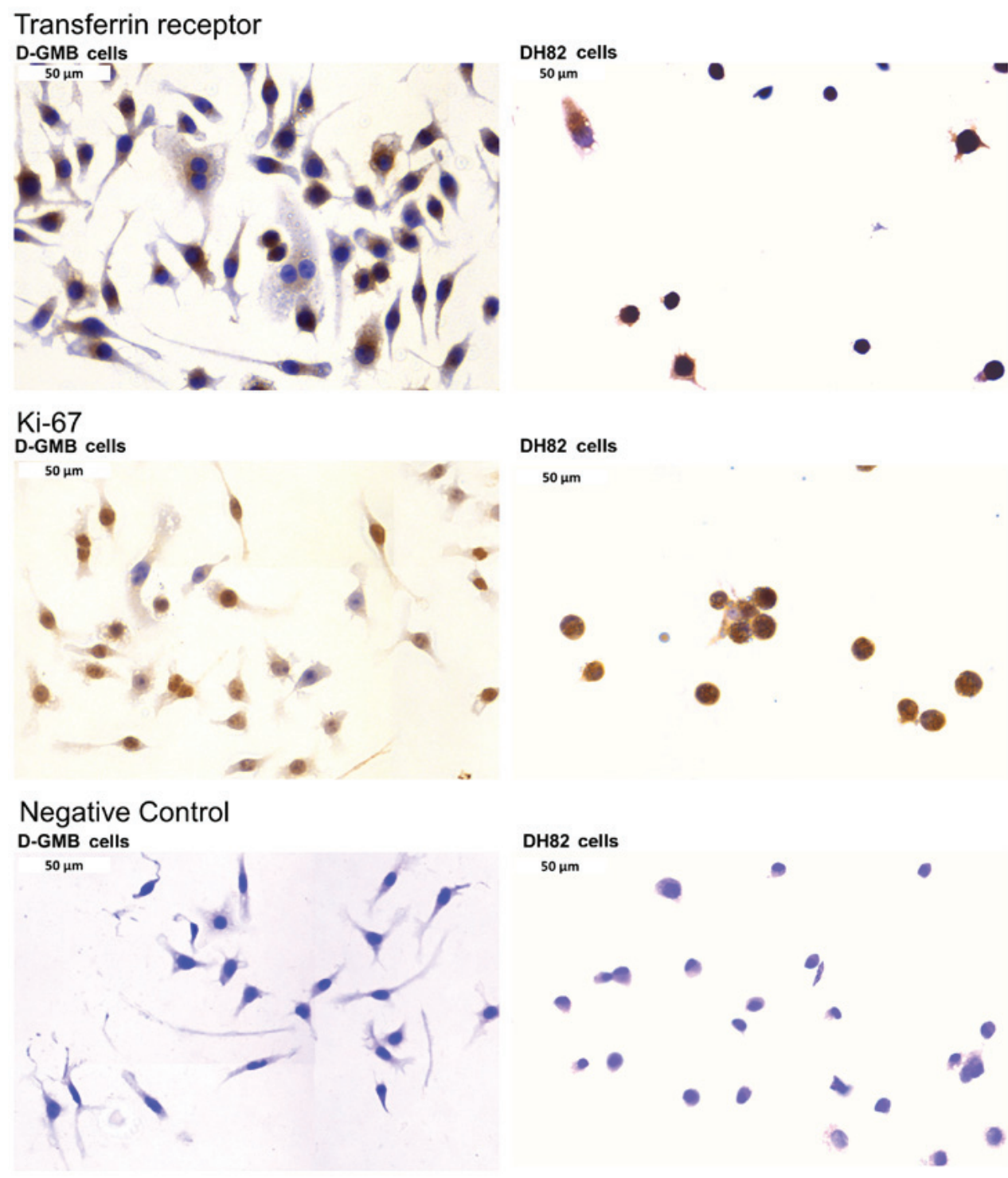

Figure 5. Detection of TfR and Ki-67 expression in dog DH82 histiocytic sarcoma and dog DGMB glioblastoma cell lines. Magnification, x40. TfR, transferrin receptor.

For comparison, the Ki-67 and TfR expression was analyzed in two dog cell lines. DH82 histiocytic sarcoma and DGMB glioblastoma cells were immunostained for both markers. Indeed, Ki-67 and TfR were overexpressed in both cell lines as presented in Fig. 5. Furthermore, the present study investigated the cytotoxicity of artemisinin, artesunate and dihydroartemisinin towards the dog cell lines. As expected, artemisinin and its derivatives were also active in these tumor cell lines. The $\mathrm{IC}_{50}$ values for artemisinin, artesunate and dihydroartemisinin towards DH82 cells and DGBM cells are presented in Fig. 6.

\section{Discussion}

It has been a matter of discussion among veterinarian physicians and alternative practitioners, whether or not supplementation of iron is beneficial for the activity of artemisinin. The role of heme has been discussed for the antimalarial activity of artemisinin and its derivatives $(57,58)$. In the context of cancer, we previously reported that Ferrosanol ${ }^{\circledR}$ and holotransferrin increase artesunate-induced cytotoxicity and apoptosis in leukemia and astrocytoma cells up to 10-fold. These effects were reversed by anti-TfR monoclonal antibody RVS10, which competes with transferrin for binding to TfR. While the TfR expression ranged between 48 and $95 \%$ in tumor cell lines, normal peripheral mononuclear blood leukocytes revealed $\leq 1.3 \% \mathrm{TfR}$ positivity, indicating that artesunate may exert tumor specific effects at least to some extent, because of the preferential TfR expression in tumor cells (59).

In a subsequent study, we investigated a total of 36 cell lines of different tumor types for their response to treatment with artesunate alone or in combination with Ferrosanol ${ }^{\circledR}(60)$. This revealed that artesunate plus Ferrosanol ${ }^{\circledR}$ enhances cytotoxicity compared with artesunate alone in the majority of cell lines; however, 11 cell lines did not demonstrate increased apoptosis and nine lines exhibited a decrease in apoptosis following the combined drug treatment compared with artesunate-treatment alone. It is understood that iron acts as co-factor for proliferation-related enzymes (61). Therefore, Ferrosanol ${ }^{\circledR}$ may induce rather than suppress the proliferation of these nine cell lines. Based on these in vitro data, it 

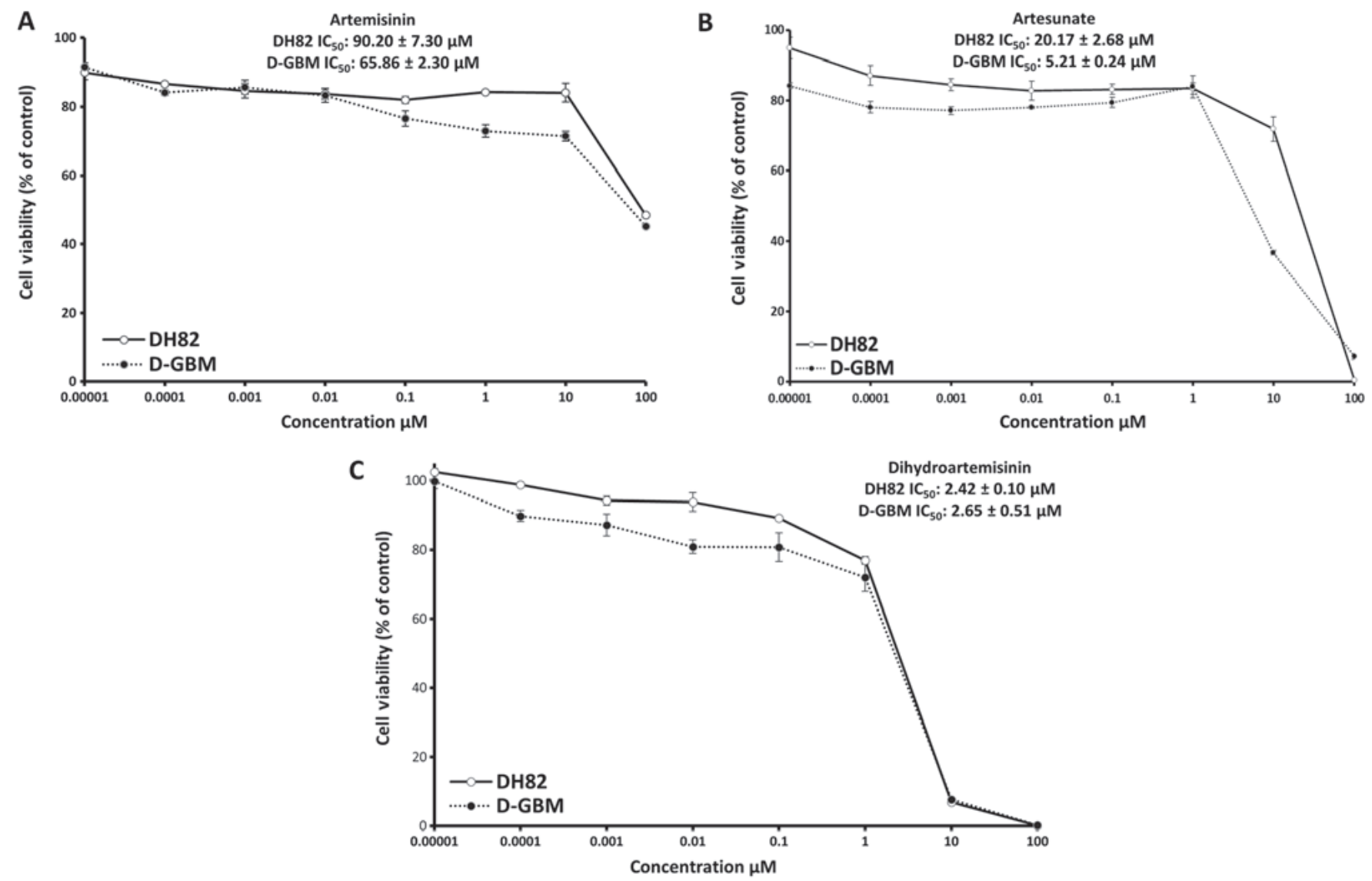

Figure 6. Cytotoxicity towards DH82 and DGMB cells as determined by a resazurin assay. (A) Artemisinin, (B) artesunate and (C) dihydroartemisinin.

cannot be reliably recommended that iron should be added as a supplement to artemisinin-type treatment in veterinary or human cancer therapy. The results of the present study revealed that the blood iron content was not associated with survival times after A. annua therapy, while the TfR content inside the tumor was. For practical reasons, it can be assumed that the normal iron content of the body should be sufficient for the activity of artesunate. Only in patients with iron-deficient conditions may iron supplementation be considered. However, in this case it may be important that iron and artesunate reach the tumor at the same time so that a possible enhancing effect of the drug combination can develop. Otherwise, Ferrosanol ${ }^{\circledR}$ may exhibit worse effects and lead to an enhancement rather than a suppression of proliferative tumor activity.

The effect of iron has also been demonstrated in other previous studies. It has been reported that the addition of transferrin can inhibit cross-resistance of multidrug-resistant H69VP small cell lung cancer cells to artemisinin (62). In addition, retinoblastoma cells with high TfR expression are more susceptible to artesunate compared with normal retina cells. This activity is specific, as RNA interference-mediated TfR-knockdown increased the sensitivity of retinoblastoma cells to artesunate (63). In accordance with these findings, supplementation with holotransferrin increases the cytotoxicity of dihydroartemisinin in T-cell lymphoma cells (64).

It is well documented that TfR is more highly expressed in tumor cells compared with normal cells $(61,65-68)$. Therefore, experimental therapy strategies have been proposed to address TfR as a treatment target to improve tumor-specific killing and spare toxic side effects to normal tissues at the same time, for example by antibody-mediated targeting of TfR or the generation of TfR-directed immunotoxins (69-71). The generation of transferrin-artemisinin conjugates revealed enhanced cytotoxicity towards tumor cells compared with uncoupled artemisinin (72-74).

Previously, we performed a clinical phase I/II trial with artesunate in 23 dogs with cancer, which revealed 1 case of complete remission and 7 cases of stable disease following artesunate-treatment (39). The results of the present retrospective study with $A$. annua appear to be improved. The present study identified an increase in survival time above the threshold of 18 months in 9 of 25 dogs (36\%). Although this trend needs to be confirmed in future studies, it could be speculated that the anticancer effect of the whole plant extract is better than that of isolated artemisinin or the semisynthetic derivative, artesunate. Indeed, the plant extract contains many more cytotoxic compounds in addition to artemisinin (75-78), including arteanuin $\mathrm{B}$, artemisitene, scopoletin and 1,8-cineole. Therefore, A. annua preparations alone may be used as a combination therapy. Several cytotoxic compounds may act at the same time against the tumor, which leads to an improved tumor inhibition.

It is well understood that rapidly proliferating tumors respond better to standard chemotherapy compared with 
slowly growing tumors $(79,80)$. Therefore, the present study also included Ki-67 as proliferation marker in the immunohistochemical analysis. Ki-67 is closely associated with the cell cycle. Its role as a predictive factor for the success of chemotherapy and as a prognostic factor for the survival of cancer patients has been discussed $(81,82)$. Therefore, the significant association between $\mathrm{Ki}-67$ expression and cytotoxicity to artemisinin in the panel of 54 human cell lines from eight different tumor types indicated that Ki-67 expression may also be a prognostic marker for tumor response to artemisinin.

The present study revealed a significant correlation between TfR and Ki-67 expression in veterinary tumors and human tumor cell lines, indicating that TfR expression is associated with high proliferative rates and that artemisinin is more active in fast growing tumors than in slowly growing ones. This result supports previous data from human tumors and also speaks for the comparability of veterinary and human tumors in this respect. The significant correlation between TfR and Ki-67 expression has been reported in biopsies of diverse tumor types, including leukemia, melanoma, breast carcinoma, brain tumors, head and neck cancer and esophageal cancer (83-88). Although a significant association was identified between TfR and Ki-67 in the entire panel of 54 tumor cell lines, this association was not seen in the majority of the subsets with different tumor types. This may simply be explained by the limited number of cell lines per tumor entity. The previously published data on the significant correlation between TfR and $\mathrm{Ki}-67$ expression were obtained in larger collectives of tumor biopsies $(83,89)$.

In human tumor pathology, hematoxylin and eosin staining is also useful for the detection of tumor-infiltrating lymphocytes (TILs) (90-92). Therefore, in the present study we also screened the hematoxylin and eosin-stained slides of the pet tumors for the presence of TILs, but TILs could not be detected in the tumor tissues. Since the tumors were generally large and already progressed at diagnosis, it was assumed that the immune system of the animals was weakened and TIL-mediated immune defenses against the tumor were largely destroyed.

Furthermore, it is important to mention that the present study did not observe considerable adverse side effects among the 25 A. annua-treated dogs and cats. In comparison to tumor treatment in human cancer patients with the semi-synthetic drug artesunate, A. annua appeared to be even safer. Among the 23 dogs with cancer treated with artesunate, fever and transient hematological and gastrointestinal toxicity were observed in 16 dogs and 1 dog died from pneumonia (39). In human cancer patients, the compassionate use of $A$. annua in 1 patient with prostate carcinoma was well tolerated in a previous study (41). Treatment with artesunate has been reported to lead to occasional and transient side effects, including hematological toxicity, gastrointestinal toxicity, asthenia and thrombosis, in colon, cervix and breast carcinoma (42-44). Rare cases of hepatotoxicity have been reported with artesunate $(93,94)$. Whether phytotherapeutic approaches with A. annua are safer than treatment with artesunate requires further investigation.

Notably, the majority of pet owners reported that the animals appeared to feel better after A. annua treatment; some were more active, while others were more relaxed. Of course, these observations are subjective and non-quantifiable, and it is unclear whether these reports may reflect the pet owners psychological condition after successful treatment of their pets. Nevertheless, this observation should not be neglected, as it cannot be excluded that there may be an unexpected and unintentional positive side effect of A. annua-treatment. Indeed, there are some previous studies that support these observations. The serotonin serum levels in the brains of artesunate-treated rabbits has been reported to be significantly higher compared with in untreated control animals (95). Zhu et al (96) reported significant remissions in nociceptive, anxiety and depressive behaviors by dihydroartemisinin, artesunate or artemether. Amos et al (97) suggested sedative properties of artemisinin mediated by artemisinin's effect on postsynaptic dopamine D2 receptors in the brain. This novel aspect of artemisinin's possible activity deserves further detailed investigation in the future.

The present investigation also raises the more general question about the comparability of data raised in veterinary tumors to the clinical situation in human tumors and thereby the suitability of veterinary tumors as models of human cancer biology and treatment. The present study determined that the role of TfR and Ki-67 was comparable between veterinary tumors and human tumor cell lines. TfR and Ki-67 have also been associated with response to artemisinin and artesunate in tumors of human patients (41-43). Although these data in human tumors are preliminary, they indicate that veterinary tumors may represent a suitable model for clinical human tumors in the context of artemisinin therapy.

Independent of this situation, there are more arguments that support the suitability of veterinary tumors for the investigation of human cancer biology. Veterinary tumors are spontaneously developing, which may qualify them as better models compared with other tumors in mice and rats. Frequently tumors are maintained by transplanting syngeneic tumors to rodents or human xenograft tumors to immunosuppressed nude mice. Another possibility is to induce tumor development in mice or rats by chemical carcinogens. Although these tumor models are indispensable and of high value in preclinical oncology, they are to some degree artificial. Here, tumors in dogs and cats may be advantageous, because their spontaneous development is closer to the situation of human tumors. Veterinary tumors have not received as much attention as the aforementioned rodent tumor models as of yet. Further investigations are required to investigate the full potential of veterinary tumors as attractive in vivo models to develop strategies for human tumor treatment.

In conclusion, the current retrospective study involving 20 dogs and cats treated with standard therapy plus A. апnиa and 11 dogs treated with standard therapy alone clearly demonstrated that additional food supplementation of A. annua to veterinary cancer patients resulted in an improved survival prognosis. The activity of A. annua may be dependent on the iron content in the tumor, but not in the blood, since TfR expression in the tumors was significantly correlated with survival time and artemisinin cytotoxicity in a control panel of human tumor cell lines. The same was true for Ki-67 expression. Tumors with high Ki-67 expression, indicating high proliferative activity, were more susceptible to artemisinin in the human cell line panel. The data presented in the present study should provide guidance for the activity of $A$. annua 
against veterinary tumors. Prospective trials are required to deliver convincing evidence for this hypothesis.

\section{Acknowledgements}

The authors wish to thank Mrs. Doris Rohr (Department of Pharmaceutical Biology, Institute of Pharmacy and Biochemistry, Johannes Gutenberg University, Mainz, Germany) for technical assistance with immunohistochemistry staining.

\section{Funding}

This study was supported by intramural funding from Johannes Gutenberg University (Mainz, Germany).

\section{Availability of data and materials}

The datasets generated and/or analyzed during the current study are not publicly available due to restrictions of the availability of these data but are available from the corresponding author on reasonable request.

\section{Authors' contributions}

TE and EB designed the study. EB treated the animals, provided the material and collected the clinical data. MEMS performed the immunostaining. MEFH performed NMR and HPLC-MS. TE performed the statistical analysis, supervised the work and provided the facilities for the study. TE and MEMS wrote the manuscript. All authors read the manuscript and approved the final version.

\section{Ethics approval and consent to participate}

Written permission for this retrospective study was obtained from the Regierungspräsidium (Government Presidium) Freiburg, Germany (Az. 35-9185.81/1, dated from February 4th, 2019). Written informed consent for experimental work was obtained from all pet owners.

\section{Patient consent for publication}

No applicable.

\section{Competing interests}

EB commercially trades Luparte ${ }^{\circledR}$. No part of the experimental work at the Department of Pharmacological Biology (Johannes Gutenberg University, Mainz, Germany) was funded by EB. All other authors declare that they have no competing interests.

\section{References}

1. Talmadge JE, Singh RK, Fidler IJ and Raz A: Murine models to evaluate novel and conventional therapeutic strategies for cancer. Am J Pathol 170: 793-804, 2007.

2. Jantscheff P, Beshay J, Lemarchand T, Obodozie C, Schächtele C and Weber H: Mouse-derived isograft (MDI) in vivo tumor models I. Spontaneous sMDI models: Characterization and cancer therapeutic approaches. Cancers (Basel) 11: 11, 2019.
3. Choi JW, Yoon HY and Jeong SW: Clinical outcomes of surgically managed spontaneous tumors in 114 client-owned dogs. Immune Netw 16: 116-125, 2016.

4. Hellmén E, Bergström R, Holmberg L, Spångberg IB, Hansson K and Lindgren A: Prognostic factors in canine mammary tumors: A multivariate study of 202 consecutive cases. Vet Pathol 30: 20-27, 1993.

5. Marconato L: The staging and treatment of multicentric high-grade lymphoma in dogs: A review of recent developments and future prospects. Vet J 188: 34-38, 2011.

6. Tuohy JL, Selmic LE, Worley DR, Ehrhart NP and Withrow SJ: Outcome following curative-intent surgery for oral melanoma in dogs: 70 cases (1998-2011). J Am Vet Med Assoc 245: 1266-1273, 2014.

7. Miller RL, Van Lelyveld S, Warland J, Dobson JM and Foale RD: A retrospective review of treatment and response of high-risk mast cell tumours in dogs. Vet Comp Oncol 14: 361-370, 2016.

8. Romano FR, Heinze CR, Barber LG, Mason JB and Freeman LM: Association between body condition score and cancer prognosis in dogs with lymphoma and osteosarcoma. J Vet Intern Med 30: 1179-1186, 2016

9. Sarowitz BN, Davis GJ and Kim S: Outcome and prognostic factors following curative-intent surgery for oral tumours in dogs: 234 cases (2004 to 2014). J Small Anim Pract 58: 146-153, 2017.

10. Ettinger SN: Principles of treatment for feline lymphoma. Clin Tech Small Anim Pract 18: 98-102, 2003.

11. Morris J: Mammary tumours in the cat: Size matters, so early intervention saves lives. J Feline Med Surg 15: 391-400, 2013.

12. Zabielska-Koczywąs K, Wojtalewicz A and Lechowski R: Current knowledge on feline injection-site sarcoma treatment. Acta Vet Scand 59: 47, 2017.

13. Martano M, Iussich S, Morello E and Buracco P: Canine oral fibrosarcoma: Changes in prognosis over the last 30 years? Vet J 241: 1-7, 2018.

14. Zhang D, Hedlund EM, Lim S, Chen F, Zhang Y, Sun B and Cao Y: Antiangiogenic agents significantly improve survival in tumor-bearing mice by increasing tolerance to chemotherapy-induced toxicity. Proc Natl Acad Sci USA 108: 4117-4122, 2011.

15. Tiwari A, Hadley JA, Hendricks GL III, Elkin RG, Cooper T and Ramachandran R: Characterization of ascites-derived ovarian tumor cells from spontaneously occurring ovarian tumors of the chicken: Evidence for E-cadherin upregulation. PLoS One 8: e57582, 2013

16. Newman DJ and Cragg GM: Natural products as sources of new drugs from 1981 to 2014. J Nat Prod 79: 629-661, 2016.

17. Tu Y: The discovery of artemisinin (qinghaosu) and gifts from Chinese medicine. Nat Med 17: 1217-1220, 2011.

18. Bridgford JL, Xie SC, Cobbold SA, Pasaje CFA, Herrmann S, Yang T, Gillett DL, Dick LR, Ralph SA, Dogovski C, et al: Artemisinin kills malaria parasites by damaging proteins and inhibiting the proteasome. Nat Commun 9: 3801, 2018.

19. Su XZ and Miller LH: The discovery of artemisinin and the Nobel Prize in Physiology or Medicine. Sci China Life Sci 58: 1175-1179, 2015.

20. Tu Y: Artemisinin-a gift from traditional chinese medicine to the world (Nobel Lecture). Angew Chem Int Ed Engl 55: 10210-10226, 2016.

21. Daddy NB, Kalisya LM, Bagire PG, Watt RL, Towler MJ and Weathers PJ: Artemisia annua dried leaf tablets treated malaria resistant to ACT and i.v. artesunate: Case reports. Phytomedicine 32: 37-40, 2017

22. Saeed ME, Krishna S, Greten HJ, Kremsner PG and Efferth T: Antischistosomal activity of artemisinin derivatives in vivo and in patients. Pharmacol Res 110: 216-226, 2016.

23. Pérez del Villar L, Burguillo FJ, López-Abán J and Muro A: Systematic review and meta-analysis of artemisinin based therapies for the treatment and prevention of schistosomiasis. PLoS One 7: e45867, 2012.

24. Naß J and Efferth T: The activity of Artemisia spp. and their constituents against Trypanosomiasis. Phytomedicine 47: 184-191, 2018.

25. Efferth T: Beyond malaria: The inhibition of viruses by artemisinin-type compounds. Biotechnol Adv 36: 1730-1737, 2018.

26. Jiang W, Cen Y, Song Y, Li P, Qin R, Liu C, Zhao Y, Zheng J and Zhou H: Artesunate attenuated progression of atherosclerosis lesion formation alone or combined with rosuvastatin through inhibition of pro-inflammatory cytokines and pro-inflammatory chemokines. Phytomedicine 23: 1259-1266, 2016. 
27. Li J, Casteels T, Frogne T, Ingvorsen C, Honore C, Courtney M, Huber KV, Schmitner N, Kimmel RA, Romanov RA, et al: Artemisinins target GABAA receptor signaling and impair alpha cell Identity. Cell 168: 86-100.e15, 2017.

28. Guo Y, Fu W, Xin Y, Bai J, Peng H, Fu L, Liu J, Li L, Ma Y and Jiang H: Antidiabetic and antiobesity effects of artemether in $\mathrm{db} / \mathrm{db}$ mice. BioMed Res Int 2018: 8639523, 2018.

29. Efferth T, Dunstan H, Sauerbrey A, Miyachi H and Chitambar CR The anti-malarial artesunate is also active against cancer. Int J Oncol 18: 767-773, 2001.

30. Efferth T, Sauerbrey A, Olbrich A, Gebhart E, Rauch P, Weber HO, Hengstler JG, Halatsch ME, Volm M, Tew KD, et al: Molecular modes of action of artesunate in tumor cell lines. Mol Pharmacol 64: 382-394, 2003.

31. Dell'Eva R, Pfeffer U, Vené R, Anfosso L, Forlani A, Albini A and Efferth T: Inhibition of angiogenesis in vivo and growth of Kaposi's sarcoma xenograft tumors by the anti-malarial artesunate. Biochem Pharmacol 68: 2359-2366, 2004.

32. Efferth T: From ancient herb to modern drug: Artemisia annua and artemisinin for cancer therapy. Semin Cancer Biol 46: 65-83, 2017.

33. Abba ML, Patil N, Leupold JH, Saeed ME, Efferth T and Allgayer $\mathrm{H}$ : Prevention of carcinogenesis and metastasis by Artemisinin-type drugs. Cancer Lett 429: 11-18, 2018

34. Krusche B, Arend J and Efferth T: Synergistic inhibition of angiogenesis by artesunate and captopril in vitro and in vivo. Evid Based Complement Alternat Med 2013: 454783, 2013.

35. Efferth T: Cancer combination therapy of the sesquiterpenoid artesunate and the selective EGFR-tyrosine kinase inhibitor erlotinib. Phytomedicine 37: 58-61, 2017.

36. Efferth T: Cancer combination therapies with artemisinin-type drugs. Biochem Pharmacol 139: 56-70, 2017.

37. Hosoya K, Murahari S, Laio A, London CA, Couto CG and Kisseberth WC: Biological activity of dihydroartemisinin in canine osteosarcoma cell lines. Am J Vet Res 69: 519-526, 2008

38. Hosoya K, Couto CG, London CA, Kisseberth WC, Phelps MA and Dalton JT: Comparison of high-dose intermittent and low-dose continuous oral artemisinin in dogs with naturally occurring tumors. J Am Anim Hosp Assoc 50: 390-395, 2014.

39. Rutteman GR, Erich SA, Mol JA, Spee B, Grinwis GC Fleckenstein L, London CA and Efferth T: Safety and efficacy field study of artesunate for dogs with non-resectable tumours Anticancer Res 33: 1819-1827, 2013

40. Berger TG, Dieckmann D, Efferth T, Schultz ES, Funk JO, Baur A and Schuler G: Artesunate in the treatment of metastatic uveal melanoma - first experiences. Oncol Rep 14: 1599-1603, 2005.

41. Michaelsen FW, Saeed ME, Schwarzkopf J and Efferth T: Activity of Artemisia annua and artemisinin derivatives, in prostate carcinoma. Phytomedicine 22: 1223-1231,2015.

42. Jansen FH, Adoubi I, JC KC, DE Cnodder T, Jansen N, Tschulakow A and Efferth T: First study of oral Artenimol-R in advanced cervical cancer: Clinical benefit, tolerability and tumor markers. Anticancer Res 31: 4417-4422, 2011.

43. Krishna S, Ganapathi S, Ster IC, Saeed ME, Cowan M, Finlayson C, Kovacsevics H, Jansen H, Kremsner PG, Efferth T, et al: A randomised, double blind, placebo-controlled pilot study of oral artesunate therapy for colorectal cancer. EBioMedicine 2: 82-90, 2014.

44. von Hagens C, Walter-Sack I, Goeckenjan M, Osburg J, Storch-Hagenlocher B, Sertel S, Elsässer M, Remppis BA, Edler L, Munzinger J, et al: Prospective open uncontrolled phase I study to define a well-tolerated dose of oral artesunate as add-on therapy in patients with metastatic breast cancer (ARTIC M33/2). Breast Cancer Res Treat 164: 359-369, 2017.

45. Breuer E and Efferth T: Treatment of iron-loaded veterinary sarcoma by Artemisia annua. Nat Prod Bioprospect 4: 113-118, 2014.

46. Hegazy MF, Abdelfatah S, Hamed AR, Mohamed TA, Elshamy AA, Saleh IA, Reda EH, Abdel-Azim NS, Shams KA, Sakr M, et al: Cytotoxicity of 40 Egyptian plant extracts targeting mechanisms of drug-resistant cancer cells. Phytomedicine 59: 152771,2019

47. Chikazawa S, Hori Y, Kanai K, Ito N, Hoshi F, Orino K, Watanabe K and Higuchi S: Factors influencing measurement of serum iron concentration in dogs: Diurnal variation and hyperferritinemia. J Vet Med Sci 75: 1615-1618, 2013.

48. Carpenter CE and Ward RE: Iron determination by Ferrozine method. In: Food Analysis Laboratory Manual. Springer, Luxembourg, pp157-159, 2017.
49. Stoica G, Lungu G, Martini-Stoica H, Waghela S, Levine J and Smith R III: Identification of cancer stem cells in dog glioblastoma. Vet Pathol 46: 391-406, 2009.

50. Wellman ML, Krakowka S, Jacobs RM and Kociba GJ: A macrophage-monocyte cell line from a dog with malignant histiocytosis. In Vitro Cell Dev Biol 24: 223-229, 1988.

51. Alley MC, Scudiero DA, Monks A, Hursey ML, Czerwinski MJ, Fine DL, Abbott BJ, Mayo JG, Shoemaker RH and Boyd MR: Feasibility of drug screening with panels of human tumor cell lines using a microculture tetrazolium assay. Cancer Res 48 589-601, 1988

52. Rubinstein LV, Shoemaker RH, Paull KD, Simon RM, Tosini S, Skehan P, Scudiero DA, Monks A and Boyd MR: Comparison of in vitro anticancer-drug-screening data generated with a tetrazolium assay versus a protein assay against a diverse panel of human tumor cell lines. J Natl Cancer Inst 82: 1113-1118, 1990.

53. Kuete V,Mbaveng AT,SandjoLP,ZeinoMandEfferth T: Cytotoxicity and mode of action of a naturally occurring naphthoquinone, 2-acetyl-7-methoxynaphtho[2,3-b]furan-4,9-quinone towards multi-factorial drug-resistant cancer cells. Phytomedicine 33: 62-68, 2017.

54. O'Brien J, Wilson I, Orton T and Pognan F: Investigation of the Alamar Blue (resazurin) fluorescent dye for the assessment of mammalian cell cytotoxicity. Eur J Biochem 267: 5421-5426, 2000.

55. Saeed ME, Mertens R, Handgretinger R and Efferth T: Identification of fatal outcome in a childhood nasopharyngeal carcinoma patient by protein expression profiling. Int J Oncol 53: 1721-1731, 2018.

56. Blaskó G, Cordell GA and Lankin DC: Definitive ${ }^{1} \mathrm{H}$-and ${ }^{13} \mathrm{C}-\mathrm{NMR}$ assignments of artemisinin (Qinghaosu). J Nat Prod 51: 1273-1276, 1988

57. Haynes RK, Cheu KW, N'Da D, Coghi P and Monti D: Considerations on the mechanism of action of artemisinin antimalarials: Part 1 - the 'carbon radical' and 'heme' hypotheses. Infect Disord Drug Targets 13: 217-277, 2013.

58. Klonis N, Creek DJ and Tilley L: Iron and heme metabolism in Plasmodium falciparum and the mechanism of action of artemisinins. Curr Opin Microbiol 16: 722-727, 2013

59. Efferth T, Benakis A, Romero MR, Tomicic M, Rauh R, Steinbach D, Häfer R, Stamminger T, Oesch F, Kaina B, et al: Enhancement of cytotoxicity of artemisinins toward cancer cells by ferrous iron. Free Radic Biol Med 37: 998-1009, 2004.

60. Kelter G, Steinbach D, Konkimalla VB, Tahara T, Taketani S, Fiebig $\mathrm{HH}$ and Efferth T: Role of transferrin receptor and the $\mathrm{ABC}$ transporters $\mathrm{ABCB} 6$ and $\mathrm{ABCB} 7$ for resistance and differentiation of tumor cells towards artesunate. PLoS One 2: e798, 2007.

61. Aulbert E, Disselhoff W, Sörje H, Schulz E and Gericke D: Lysosomal accumulation of $67 \mathrm{Ga}$ - transferrin in malignant tumors in relation to their growth rate. Eur J Cancer 16: 1217-1232, 1980

62. Sadava D, Phillips T, Lin C and Kane SE: Transferrin overcomes drug resistance to artemisinin in human small-cell lung carcinoma cells. Cancer Lett 179: 151-156, 2002.

63. Zhao F, Wang H, Kunda P, Chen X, Liu QL and Liu T: Artesunate exerts specific cytotoxicity in retinoblastoma cells via CD71. Oncol Rep 30: 1473-1482, 2013.

64. Wang Q, Wu S, Zhao X, Zhao C, Zhao H and Huo L: Mechanisms of dihydroartemisinin and dihydroartemisinin/holotransferrin cytotoxicity in t-cell lymphoma cells. PLoS One 10: e0137331, 2015.

65. Judd W, Poodry CA and Strominger JL: Novel surface antigen expressed on dividing cells but absent from nondividing cells. J Exp Med 152: 1430-1435, 1980

66. Sutherland R, Delia D, Schneider C, Newman R, Kemshead J and Greaves M: Ubiquitous cell-surface glycoprotein on tumor cells is proliferation-associated receptor for transferrin. Proc Natl Acad Sci USA 78: 4515-4519, 1981.

67. Trowbridge IS and Omary MB: Human cell surface glycoprotein related to cell proliferation is the receptor for transferrin. Proc Natl Acad Sci USA 78: 3039-3043, 1981.

68. Gatter KC, Brown G, Trowbridge IS, Woolston RE and Mason DY: Transferrin receptors in human tissues: Their distribution and possible clinical relevance. J Clin Pathol 36: 539-545, 1983.

69. Tortorella S and Karagiannis TC: Transferrin receptor-mediated endocytosis: A useful target for cancer therapy. J Membr Biol 247: 291-307, 2014.

70. Luria-Pérez R,Helguera G and Rodríguez JA: Antibody-mediated targeting of the transferrin receptor in cancer cells. Bol Méd Hosp Infant México 73: 372-379, 2016. 
71. Akbari B, Farajnia S, Ahdi Khosroshahi S, Safari F, Yousefi M, Dariushnejad $\mathrm{H}$ and Rahbarnia L: Immunotoxins in cancer therapy: Review and update. Int Rev Immunol 36: 207-219, 2017.

72. Lai H, Sasaki T, Singh NP and Messay A: Effects of artemisinin-tagged holotransferrin on cancer cells. Life Sci 76: $1267-1279,2005$

73. Nakase I, Gallis B, Takatani-Nakase T, Oh S, Lacoste E, Singh NP, Goodlett DR, Tanaka S, Futaki S, Lai H, et al: Transferrin receptor-dependent cytotoxicity of artemisinin-transferrin conjugates on prostate cancer cells and induction of apoptosis Cancer Lett 274: 290-298, 2009.

74. Gong Y, Gallis BM, Goodlett DR, Yang Y, Lu H, Lacoste E, Lai H and Sasaki T: Effects of transferrin conjugates of artemisinin and artemisinin dimer on breast cancer cell lines. Anticancer Res 33: 123-132, 2013

75. Zhong YR: Chemical constituents of volatile oils of Artemisia annua. Zhong Yao Tong Bao 8: 31-32, 1983 (In Chinese).

76. Liao HW, Wang DY and Li XM: Studies on the chemical constituents of essential oil of Hunan Artemisia annua. Zhong Yao Cai 29: 562-564, 2006 (In Chinese).

77. Efferth T, Herrmann F, Tahrani A and Wink M: Cytotoxic activity of secondary metabolites derived from Artemisia annua L. towards cancer cells in comparison to its designated active constituent artemisinin. Phytomedicine 18: 959-969, 2011

78. Zhang X, Zhao Y, Guo L, Qiu Z, Huang L and Qu X: Differences in chemical constituents of Artemisia annua L. from different geographical regions in China. PLoS One 12: e0183047, 2017.

79. Efferth T, Konkimalla VB, Wang YF, Sauerbrey A, Meinhardt S, Zintl F, Mattern J and Volm M: Prediction of broad spectrum resistance of tumors towards anticancer drugs. Clin Cancer Res 14: 2405-2412, 2008

80. Volm M and Efferth T: Prediction of cancer drug resistance and implications for personalized medicine. Front Oncol 5: 282, 2015.

81. Duffy MJ, Harbeck N, Nap M, Molina R, Nicolini A, Senkus E and Cardoso F: Clinical use of biomarkers in breast cancer: Updated guidelines from the European Group on Tumor Markers (EGTM). Eur J Cancer 75: 284-298, 2017.

82. Sun $X$ and Kaufman PD: Ki-67: More than a proliferation marker. Chromosoma 127: 175-186, 2018.

83. Scott CS, Ramsden W, Limbert HJ, Master PS and Roberts BE: Membrane transferrin receptor (TfR) and nuclear proliferation-associated Ki-67 expression in hemopoietic malignancies. Leukemia 2: 438-442, 1988.

84. Soyer HP, Smolle J, Smolle-Juettner FM and Kerl H: Proliferation antigens in cutaneous melanocytic tumors - an immunohistochemical study comparing the transferrin receptor and the Ki-67 antigen. Dermatologica 179: 3-9, 1989.

85. Wrba F, Chott A, Reiner A, Reiner G, Markis-Ritzinger E and Holzner JH: Ki-67 immunoreactivity in breast carcinomas in relation to transferrin receptor expression, estrogen receptor status and morphological criteria. An immunohistochemical study. Oncology 46: 255-259, 1989.
86. Prior R, Reifenberger G and Wechsler W: Transferrin receptor expression in tumours of the human nervous system: Relation to tumour type, grading and tumour growth fraction. Virchows Arch A Pathol Anat Histopathol 416: 491-496, 1990.

87. Kearsley JH, Furlong KL, Cooke RA and Waters MJ: An immunohistochemical assessment of cellular proliferation markers in head and neck squamous cell cancers. Br J Cancer 61: 821-827, 1990.

88. Chan KT, Choi MY, Lai KK, Tan W, Tung LN, Lam HY, Tong DK, Lee NP and Law S: Overexpression of transferrin receptor CD71 and its tumorigenic properties in esophageal squamous cell carcinoma. Oncol Rep 31: 1296-1304, 2014.

89. Motamedi M, Xu L and Elahi S: Correlation of transferrin receptor (CD71) with Ki67 expression on stimulated human and mouse T cells: The kinetics of expression of $\mathrm{T}$ cell activation markers. J Immunol Methods 437: 43-52, 2016.

90. Darb-Esfahani S, Kolaschinski I, Trillsch F, Mahner S, Concin N, Vergote I, Van Nieuwenhuysen E, Achimas-Cadariu P, Glajzer J, Woopen $\mathrm{H}$, et al: Morphology and tumour-infiltrating lymphocytes in high-stage, high-grade serous ovarian carcinoma correlated with long-term survival. Histopathology 73: 1002-1012, 2018.

91. Lee JS, Won HS, Sun S, Hong JH and Ko YH: Prognostic role of tumor-infiltrating lymphocytes in gastric cancer: A systematic review and meta-analysis. Medicine (Baltimore) 97: e11769, 2018.

92. Shen M, Wang J and Ren X: New insights into tumor-infiltrating $\mathrm{B}$ lymphocytes in breast cancer: Clinical impacts and regulatory mechanisms. Front Immunol 9: 470, 2018.

93. Uhl M, Schwab S and Efferth T: Fatal liver and bone marrow toxicity by combination treatment of dichloroacetate and artesunate in a glioblastoma multiforme patient: Case report and review of the literature. Front Oncol 6: 204, 2016.

94. Efferth T, Schöttler U, Krishna S, Schmiedek P, Wenz F and Giordano FA: Answer to the comment of Hai Lu et al. regarding 'Hepatotoxicity by combination treatment of temozolomide, artesunate and Chinese herbs in a glioblastoma multiforme patient: Case report and review of the literature. Arch Toxicol (2016)'. Arch Toxicol 91: 2491-2492, 2017.

95. Eigbibhalu UG, Albert Taiwo EO, Douglass IA and Abimbola EA: Effect of selected anti-malarial drugs on the blood chemistry and brain serotonin levels in male rabbits. Pak J Pharm Sci 26: 125-129, 2013.

96. Zhu CY, Xu QH, Mao ZY and Lin N: Application of three artemisinin derivatives in neuropathic pain: Evaluating co-curation of nociceptive and emotional syndromes in spinal cord ligation mice. Zhongguo Zhong Yao Za Zhi 43: 3058-3063, 2018 (In Chinese).

97. Amos S, Chindo BA, Abbah J, Vongtau HO, Edmond I, Binda L, Akah PA, Wambebe C and Gamaniel KS: Postsynaptic dopamine $(\mathrm{D}(2))$-mediated behavioural effects of high acute doses of artemisinin in rodents. Brain Res Bull 62: 255-260, 2003.

This work is licensed under a Creative Commons Attribution-NonCommercial-NoDerivatives 4.0 International (CC BY-NC-ND 4.0) License. 